\title{
$\mathrm{Na}+$-dependent transporters
}

DOI:

10.1016/j.ceca.2019.102136

\section{Document Version}

Accepted author manuscript

Link to publication record in Manchester Research Explorer

\section{Citation for published version (APA):}

Verkhratsky, A., \& Rose, C. R. (2020). Na+-dependent transporters: The backbone of astroglial homeostatic function. Cell calcium, 85(1), 102136. [102136]. https://doi.org/10.1016/j.ceca.2019.102136

\section{Published in:}

Cell calcium

\section{Citing this paper}

Please note that where the full-text provided on Manchester Research Explorer is the Author Accepted Manuscript or Proof version this may differ from the final Published version. If citing, it is advised that you check and use the publisher's definitive version.

\section{General rights}

Copyright and moral rights for the publications made accessible in the Research Explorer are retained by the authors and/or other copyright owners and it is a condition of accessing publications that users recognise and abide by the legal requirements associated with these rights.

\section{Takedown policy}

If you believe that this document breaches copyright please refer to the University of Manchester's Takedown Procedures [http://man.ac.uk/04Y6Bo] or contact uml.scholarlycommunications@manchester.ac.uk providing relevant details, so we can investigate your claim.

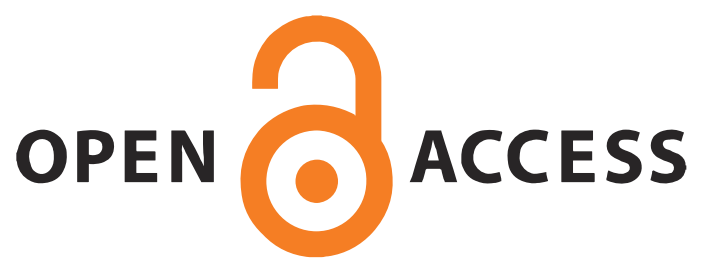




\title{
$\mathrm{Na}^{+}$-dependent transporters: the backbone of astroglial homeostatic function
}

\author{
Alexei Verkhrastky ${ }^{1,2}$ \& Christine R. Rose ${ }^{3}$ \\ ${ }^{1}$ Faculty of Biology, Medicine and Health, The University of Manchester, \\ Manchester, M13 9PT, UK; ${ }^{2}$ Achucarro Centre for Neuroscience, IKERBASQUE, \\ Basque Foundation for Science, 48011, Bilbao, Spain; \\ ${ }^{3}$ Institute of Neurobiology, Faculty of Mathematics and Natural Sciences, Heinrich \\ Heine University Düsseldorf, Universitätsstrasse 1, D-40225 Düsseldorf, Germany
}

Running Title: $\mathrm{Na}^{+}$-dependent glial transporters

*Corresponding author:

Professor Alexei Verkhratsky, The University of Manchester, Oxford Road, Manchester, M13 9PT, UK, Telephone +44 (0)161-2755414, e-mail:

Alexej.Verkhratsky@manchester.ac.uk 


\begin{abstract}
Astrocytes are the principal homeostatic cells of the central nerves system (CNS) that support the CNS function at all levels of organisation, from molecular to organ. Several fundamental homeostatic functions of astrocytes are mediated through plasmalemmal pumps and transporters; most of which are also regulated by tarnsplasmalemmal gradient of $\mathrm{Na}^{+}$ions. Neuronal activity as well as mechanical or chemical stimulation of astrocytes trigger plasmalemmal $\mathrm{Na}^{+}$fluxes, which in turn generate spatio-temporally organised transient changes in cytosolic $\mathrm{Na}^{+}$ concentration, which represent the substrate of astroglial $\mathrm{Na}^{+}$signalling. Astroglial $\mathrm{Na}^{+}$signals link and coordinate neuronal activity and CNS homeostatic demands with astroglial homeostatic response.
\end{abstract}

Key words: Astrocyte; SLC transporters, $\mathrm{Na}^{+} / \mathrm{K}^{+}$pump; $\mathrm{Na}^{+}$signalling; neurotransmission 


\section{Astrocytes: Homeostatic cells of the CNS}

The central nervous system (CNS) is composed from several distinct cellular populations of different origin represented by neural cells (neurones and macroglia), immunocompetent microglia and cells of blood vessels (muscle cells, endothelial cells and pericytes). Neuronal activity, which is chiefly responsible for information processing, demands substantial metabolic support and tight control over interstitial concentration of ions and neurotransmitters. Highly active neuronal metabolism necessitates control over reactive oxygen species, while neuronal enzymes produce proteinaceous waste that needs to be collected and jettisoned. Lifelong remodelling and reshaping of synaptic connections, which underlies neuronal plasticity, learning and memory, requires synaptogenesis and synaptic elimination, whereas micro-lesions that inevitably occur during life require rapid mending. In short, the function of CNS presents a formidable homeostatic challenge, which is met by a dedicated class of neural cells - the neuroglia.

Neuroglia of the CNS comprise macroglia of ectodermal origin, which is further subclassified into astroglia, oligodendroglia and NG-2 glia (also known as oligodendroglial precursor cells (OPC), polydendrocytes or synantocytes). A second class of neuroglia is represented by the microglial cells, which are of mesodermal origin. Precursors of microglial cells invade the neural tube very early in the embryonic development and disseminate throughout the CNS. They acquire an array of receptors for neurotransmitters and neurohormones as well as for pathologyassociated molecules; these latter being the legacy of the myeloid lineage they are derived from. The raison d'etre of neuroglia and their foremost function is preservation of the homeostasis of the CNS, support of neuronal function, myelination of axons, assistance in synaptogenesis and protection of the nervous tissue (for further details and references see [1-13]).

Astrocytes are principal homeostatic cells which populate both grey and white matter of all regions of the CNS. Astrocytes represent a rather heterogeneous group of cells and several major classes can be distinguished based on their morphology and function (Fig. 1): (i) radial glia representing neural stem cell during brain development (ii) protoplasmic astrocytes of the grey matter; (iii) fibrous astrocytes of the white matter; (iv) several types of specialised astrocytes including velate astrocytes of the cerebellum, marginal astrocytes, pituicytes of the neuro-hypophysis, Gomori astrocytes localised in the arcuate nucleus of the hypothalamus and in the hippocampus, surface-associated astrocytes and perivascular astrocytes; (v) radial astrocytes, which are represented by cerebellar Bergmann glial cells, radial stem astrocytes of the neurogenic niches, tanycytes residing in hypothalamus and in some parts of the spinal cord and Müller retinal glial cells; (vi) ependymocytes, choroid plexus cells and retinal pigment epithelial cells [14]. The brains of humans and high primates also possess different other specialised astrocytes with yet unknown functions; these cells are classified as interlaminar, polarised and varicose projection astrocytes [15-17].

Despite this pronounced heterogeneity and diversity, the main function of all astroglia (even including dedicated stem cells) is the maintenance of CNS homeostasis at all levels of organisation. Astrocytes control the molecular homeostasis of the extracellular space; this includes demand over the ion composition of the interstitium 
(the ionostasis) and the turnover and concentration of neurotransmitters. Astrocytes remove and catabolise several major neurotransmitters, including glutamate, GABA, noradrenaline and adenosine. Furthermore astrocytes supply neurones with neurotransmitter precursors (notably with glutamine that is an obligatory precursor for glutamate and GABA); and astrocytes convert several pro-forms of growth factors and hormones into active forms (this includes BDNF and thyroid hormones), Astrocytes represent a fundamental element controlling synaptic connectivity and transmission. In particular, astrocytes support synaptogenesis and synaptic maturation, provide for synaptic isolation and synaptic maintenance and contribute to synaptic extinction, hence forming a "synaptic cradle" [18, 19]). Astroglial cells support metabolic homeostasis of the nervous tissue by supplying energy substrates and synthesising glycogen, they contribute to the local regulation of the blood flow, and regulate the volume of extracellular space through transport of water. Astrocytes are a central part of organ homeostasis being responsible for maintenance of the bloodbrain barrier and function of the lymphatic system, and astrocytes are involved in systemic regulation being the chemosensing cells perceiving fluctuations of oxygen, $\mathrm{CO}_{2}$, systemic sodium and glucose. Finally, astroglial cells provide for neuroprotection in both healthy and pathological conditions; for example astrocytes contribute to scavenging of reactive oxygen species, and astrocytes protect neurones against excitotoxicity. In pathological conditions, astrocytes instigate defensive remodelling generally known as reactive astrogliosis. For relevant literature and references we refer the reader to several recent reviews [14, 20-23].

\section{Astroglial homeostatic transporters}

In this essay we shall concentrate on astroglial molecular mechanisms responsible for molecular homeostasis. Astrocytes are actively engaged in the transport of ions, neurotransmitters, hormones, various transmitter and hormonal precursors, energy substrates, amino acids etc. Most of this transport is accomplished by plasmalemmal transporters, genes for which are the most represented in the astrocytic transcriptome $[24,25]$. Membrane transporters are generally classified into (i) pumps or ATPdependent transporters, which hydrolyze ATP and use the released energy to move molecules against their electro-chemical gradients and (ii) the solute carrier transporters (SLCs) that utilize the energy saved in the electrochemical gradients of different ions to transport ions or other small molecules. The SLCs are further divided into (a) uniporters which translocate ions or molecules along concentration gradients; (b) co-transporters which are represented by symporters and antiporters that accomplish translocation of ions/molecules against the concentration gradients by using electrochemically beneficial movement of other ions or molecules either in the same or in the opposite direction, respectively. The human genome contains 1020 genes encoding membrane transporters. The membrane transporters expressed in astrocytes accomplish various functional roles and here we classify them into (i) transporters responsible for ion homeostasis or ionostasis; (ii) neurotransmitter transporters; (iii) transporters of neurotransmitter precursors; (iv) and metabolite transporters (Figs 2 - 5).

\section{Ionostatic transporters}

\subsection{Ion ATP-ases}


Like most living cells, astroglial membranes (plasma membrane and endomembranes) contain three classes of ion-moving ATPases which are classified as [26] P-type ATPases (named so because of the involvement of phosphorylated protein intermediate, V (vacuolar)-type ATPases and F-type ATPases (being part of mitochondrial ATP synthesising cascade).

\subsubsection{The $\mathrm{Na}^{+}-\mathrm{K}^{+}$ATPase, or sodium-potassium pump or NKA}

The NKA is a P-type ATPase and one of the central enzymes of astroglial physiology that generates transmembrane gradients for $\mathrm{Na}^{+}$and $\mathrm{K}^{+}$, which by proxy define astroglial membrane potential and control a multitude of membrane transporters. The NKA catalyses the transmembrane movement of $\mathrm{Na}^{+}$and $\mathrm{K}^{+}$with stoichiometry of $3 \mathrm{Na}^{+}$, which are exported from the cell, and $2 \mathrm{~K}^{+}$, which are imported into the cell (Fig. 2). The difference in charges transported in and out of the cell makes the NKA electrogenic; its activation generates a net outward current. The NKA is a transmembrane protein composed of the catalytic $\alpha$ subunit (that binds ATP and the NKA antagonist ouabain), the $\beta$-subunit required for pump operation, and an associated $\gamma$ or FXYD subunit that probably regulates the affinity of the NKA to $\mathrm{K}^{+}$ and $\mathrm{Na}^{+}$[27]. There are four $\alpha$ and three $\beta$ subunits which are differentially expressed in various tissues and have distinct tissue and cell localisation [28]. In the brain and in the spinal cord, the $\alpha 1$ subunit is expressed in both neurones and glia, the $\alpha 2$ subunit appears specifically in astrocytes, while the $\alpha 3$ subunit is mainly present in neurones $[29,30]$.

Specific expression of $\alpha 2$ subunits defines distinct properties of the astroglial NKA. The affinity of the neuronal NKA assembled as for $\alpha 1 \beta 1, \alpha 1 \beta 2, \alpha 3 \beta 1$ and $\alpha 3 \beta 2$ complexes to extracellular $\mathrm{K}^{+}$is quite high, with $\left[\mathrm{K}^{+}\right]_{0.5}$ ranging from $0.25-0.65 \mathrm{mM}$. In contrast, the $\left[\mathrm{K}^{+}\right]_{0.5}$ for $\alpha 2 \beta 1$ assembly, a typical astroglial composition, is around $3.6 \mathrm{mM}$ [31]. As a result, astroglial NKA can be activated by physiological changes in the extracellular $\left[\mathrm{K}^{+}\right]$. Neuronal NKA, in contrast is fully saturated already at rest and therefore is regulated solely by changes in intracellular $\left[\mathrm{Na}^{+}\right]$[31-34]. The low affinity to $\mathrm{K}^{+}$defines the principal role of NKA in astroglial buffering of extracellular $\mathrm{K}^{+}$; as indeed NKA provides for local $\mathrm{K}^{+}$uptake during periods of neuronal activity. Disruption of astrocytic NKA (resulting for example from loss of function mutation of a2) impairs $\mathrm{K}^{+}$buffering and (in proxy) glutamate uptake which may result in neurological conditions such as familial hemiplegic migraine type 2 [35].

\subsubsection{Plasmalemmal and endoplasmic reticulum $\mathrm{Ca}^{2+}$-ATPases}

The $\mathrm{Ca}^{2+}$ pump of plasma membrane, or plasmalemmal $\mathrm{Ca}^{2+}$-ATPase (PMCAs 1 - 4; Fig. 2) represents a central element of $\mathrm{Ca}^{2+}$ homeostasis, being one the major pathways for $\mathrm{Ca}^{2+}$ removal from the cytoplasm [36, 37]. The PMCA is essentially a $\mathrm{Ca}^{2+} / \mathrm{H}^{+}$exchanger with a stoichiometry $1 \mathrm{Ca}^{2+}$ (out) : $1 / 2 \mathrm{H}^{+}$(in). This $\mathrm{Ca}^{2+}$ pump has a high affinity to $\mathrm{Ca}^{2+}$, with a $\mathrm{K}_{\mathrm{D}}$ ranging between 10 and $20 \mu \mathrm{M}$ in resting conditions; calmodulin reduces the $\mathrm{K}_{\mathrm{D}}$ to $\sim 1 \mu \mathrm{M}$ [38].

Astrocytes in vitro were found to express (at mRNA and protein levels) PMCA1, PMCA4 and to a lesser extend PMCA2 [39]. In addition to PMCA, astrocytes possess the Sarco(Endo)Plasmic Reticulum $\mathrm{Ca}^{2+}$-ATP-ase (SERCA) responsible for $\mathrm{Ca}^{2+}$ 
accumulation into endoplasmic reticulum $\mathrm{Ca}^{2+}$ store. Astrocytes predominantly express the SERCA2b subtype of this $\mathrm{Ca}^{2+}$ pump [40].

\subsubsection{V-type and F-type ATPases}

Both F- and V-type ATPases are $\mathrm{H}^{+}$pumps. The F-type ATPase (or ATP synthase) is expressed in mitochondria. The $\mathrm{V}$ (vacuolar)-type $\mathrm{H}^{+}$pumps are present in astrocytes in the plasmalemma ( 35\% of total amount), in lysosomes and in secretory vesicles where they provide for an acidic intraluminal environment driving vesicular neurotransmitter transporters [41, 42].

\subsection{Ionostatic SLC transporters}

\subsubsection{Plasmalemmal sodium-calcium exchanger NCX}

The plasmalemmal $\mathrm{Na}^{+}-\mathrm{Ca}^{2+}$ exchanger (NCX), a member of SLC8 transporter family, is a central molecule of cellular $\mathrm{Ca}^{2+}$ and $\mathrm{Na}^{+}$homeostatic and signalling systems [34, 38, 43] (Fig. 2). The NCX represents a low-affinity, high-capacity $\mathrm{Ca}^{2+}$ transporting system [38]. There are three versions of the NCX each encoded by a separate gene; these are classified as NCX1/SLC8A1, NCX2/ SLC8A2 and NCX3/SLC8A3 [44]. All three NCX types are expressed in astrocytes; with possible prevalence of NCX1 [45]. NCX molecules concentrate in astroglial perisynaptic processes, sharing this strategic location with glutamate transporters and the NKA $[30,46,47]$.

The NCX utilises the electrochemical gradients for $\mathrm{Ca}^{2+}$ and $\mathrm{Na}^{+}$and operates in both forward $\left(\mathrm{Ca}^{2+}\right.$ extrusion) and reverse $\left(\mathrm{Ca}^{2+}\right.$ influx $)$ modes, the switch between these modes being determined by the membrane potential as well as by the extra- and intracellular concentrations of both ions. The stoichiometry of all three NCXs is $3 \mathrm{Na}^{+}: 1 \mathrm{Ca}^{2+}$. Typical resting concentrations of $\mathrm{Na}^{+}$and $\mathrm{Ca}^{2+}$ in astroglial cytosol and in the extracellular milieu are $\sim 15 \mathrm{mM}$ for $\left[\mathrm{Na}^{+}\right]_{\mathrm{i}}$ and $\sim 150 \mathrm{mM}$ for $\left[\mathrm{Na}^{+}\right]_{\mathrm{o}}$ and $\sim 50-$ $150 \mathrm{nM}$ for $\left[\mathrm{Ca}^{2+}\right]_{\mathrm{i}}$ and $\sim 1.4 \mathrm{mM}$ for $\left[\mathrm{Ca}^{2+}\right]_{0}$. The reversal potential for NCX calculated for these conditions using modified and reduced Nernst equation $\left(\mathrm{E}_{\mathrm{NCX}}=\right.$ $\left(n E_{N a}-2 E_{C a}\right) /(n-2)$; where $n$ is the number of transported $\mathrm{Na}^{+}$, while $E_{\mathrm{Na}}$ and $\mathrm{E}_{\mathrm{Ca}}$ are equilibrium potentials of $\mathrm{Na}^{+}$and $\mathrm{Ca}^{2+}$ ) lies around $-85 \mathrm{mV}$, which is very close to the resting membrane potential of astroglial cells. This consequently implies that astroglial NCX seem to fluctuate between forward and reverse mode and even minor shifts in $\mathrm{V}_{\mathrm{m}}$ or in intercellular ion concentration rapidly switch the operational direction of the exchanger. As a result, NCX dynamically regulates the kinetics and time course of $\mathrm{Ca}^{2+}$ and $\mathrm{Na}^{+}$signals in astrocytes, coordinating them with neuronal activity that almost invariably results in plasmalemmal $\mathrm{Na}^{+}$or $\mathrm{Ca}^{2+}$ influx $\left(\mathrm{Na}^{+}\right.$ entering through glutamate transporters and cationic channels; the latter also act as conduit for $\mathrm{Ca}^{2+}$ ions - [34, 48-51]). Experimentally, both forward and reverse mode of NCX operation in astrocytes have been documented in vitro and in situ [52-58]. Furthermore, NCX operating in the reverse mode in conditions of depolarisation and increased $\left[\mathrm{Na}^{+}\right]_{\mathrm{i}}$ may be fully sufficient to generate and maintain local $\mathrm{Ca}^{2+}$ signal microdomains in perisynaptic astroglial processes without any need for additional activation of $\mathrm{Ca}^{2+}$ permeable channels [59].

\subsubsection{Sodium-potassium-chloride co-transporter NKCC1}


The $\mathrm{Na}^{+}-\mathrm{K}^{+}-\mathrm{Cl}^{-}$co-transporter 1 (NKCC1/SLC12A2) is a symporter that translocates $\mathrm{Na}^{+}, \mathrm{K}^{+}$and $\mathrm{Cl}^{-}$into the cell with an electroneutral stoichiometry of $1 \mathrm{Na}^{+}: 1 \mathrm{~K}^{+}: 2 \mathrm{Cl}^{-}$ [60] (Fig. 2). Expression of this transporter in astroglial cells has been demonstrated at both transcriptional and protein levels [61-63]. Its operation was functionally characterised in experiments in cell culture, in isolated optic nerve and in brain slices [62, 64-67]. In Bergmann glial cells studied in situ, NKCC1 was found to be responsible for maintaining high $(35-50 \mathrm{mM}) \mathrm{Cl}^{-}$concentration in the cytoplasm [67]. Conversely, experiments in hippocampal slices failed to detect NKCC1 role in ion transport in protoplasmic astrocytes [31]. In luminal membranes of cells of the choroid plexus, in contrast, NKCC1 operates in the outward mode, contributing to the production of cerebrospinal fluid [68].

The SLC12 family of cation-Cl- co-transporters also includes rather widespread $\mathrm{K}^{+}$$\mathrm{Cl}^{-}$co-transporters (represented by 4 subtypes SLC12/A1 - A4), which extrude $\mathrm{Cl}^{-}$ from cells. Data on expression of KCC transporters in astrocytes are rather fragmentary [61, 69], and evidence of functional expression of these molecules in astroglial cells in vivo are not available.

\subsubsection{Sodium-proton exchanger NHE}

Astrocytes express NHE1/SLC9A1 sodium-proton exchanger which represents the main system for extruding $\mathrm{H}^{+}$from astrocytes [70, 71] (Fig. 2). Protons are continuously accumulated in astrocytes being generated by metabolism and imported with operational cycles of glutamate transporters (see below) and $\mathrm{Ca}^{2+}$ extrusion (plasmalemmal $\mathrm{Ca}^{2+}$ pump brings $2 \mathrm{H}^{+}$into the cytoplasm for each $\mathrm{Ca}^{2+}$ ion expelled). The NHE1 operates with electroneutral (single $\mathrm{Na}^{+}$is exchanged for single $\mathrm{H}^{+}$) stoichiometry [72]. The reversal potential of NHE1 lies at positive levels ensuring that this transporter excretes $\mathrm{H}^{+}$across the entire range of physiological $\mathrm{V}_{\mathrm{m}}$.

\subsubsection{Sodium-bicarbonate co-transporter NBCe1}

The $\mathrm{Na}^{+}$-dependent bicarbonate transporter NBCe1/SLC4A4, together with NHE, is the main molecule of astroglia-dependent control over $\mathrm{pH}[70,71]$. The stoichiometry of the NBCe1 is $1 \mathrm{Na}^{+}: 2 \mathrm{HCO}_{3}{ }^{-}$or $1 \mathrm{Na}^{+}: 3 \mathrm{HCO}_{3}{ }^{-}$which thus provides for a net influx of 1 or 2 negative charges, defining transporter electrogeneity [73]. In astrocytes, the equilibrium potential for NBCe1 is around $-70 \mathrm{mV}$ and thus physiological changes in $\left[\mathrm{Na}^{+}\right]_{\mathrm{i}}$ and/or $\mathrm{V}_{\mathrm{m}}$ may change the mode of transporter operation [74, 75]. The transporter may thus operate in forward mode (that mediates influx of $\mathrm{Na}^{+}$and $\mathrm{HCO}_{3}{ }^{-}$into the cell) or in reverse mode, in which $\mathrm{Na}^{+}$and $\mathrm{HCO}_{3}{ }^{-}$ are exported to the extracellular space. Expression and functional activity of NBCe1 was detected in astrocytes in culture [76] and in acute hippocampal slices [77].

\section{Neurotransmitter transporters}

Astrocytes are central cellular elements regulating uptake and catabolism of major neurotransmitters in the CNS. Astroglial cells remove glutamate (which is converted into glutamine by astroglial specific glutamate synthetase), GABA (which is degraded by feeding into the Krebs cycle), adenosine (which is converted into inosine through 
astroglia-specific adenosine kinase) and noradrenaline and other catecholamines (which are catabolised by astroglia-specific monoaminoxidase-B).

\section{1. $\mathrm{Na}^{+}$-dependent glutamate transporters EAAT1/2}

Astrocytes are the main sink of glutamate in the CNS; by removing glutamate from the extracellular space, astrocytes regulate neurotransmission and prevent excitotoxicity. Astroglial uptake of glutamate is mediated by two types of $\mathrm{Na}^{+}-$ dependent amino acid transporters EAAT1/SLC1A6 and EAAT2/SLC1A2, which in experiments on rodents are often referred to as GLAST1 (glutamate-aspartate transporter 1 [78], and GLT-1 (glutamate transporter 1 [79]) (Fig. 3). Molecularly, EAATs are homotrimers with several splice variants [80]. In the CNS, EAAT1 and EAAT2 are expressed predominantly in astrocytes, with EAAT1 being highly expressed in radial astrocytes of stem cell niches, in the retina, in circumventricular organs, and in the cerebellum, whereas EAAT2 prevails in all other regions [81-84]. Astrocytes contain very high levels of glutamate transporters: the density of EAAT1 approaches $\sim 4700 / \mu \mathrm{m}^{2}$ in cerebellar Bergmann glial cells and $\sim 2300 / \mu \mathrm{m}^{2}$ in astrocytes in the CA1 region of the hippocampus. The density of EAAT2 is $8500 / \mu \mathrm{m}^{2}$ in hippocampal and $\sim 740 / \mu \mathrm{m}^{2}$ in cerebellar cells [82]. Most EAATs are expressed in astroglial perisynaptic processes [85].

The transport of a single glutamate molecule is accomplished with a stoichiometry of 1 Glu: $3 \mathrm{Na}^{+}: 1 \mathrm{H}^{+}$(in) $/ 1 \mathrm{~K}^{+}$(out) (Fig. 3). The Erev of the transporter depends on ion gradients and cytoplasmic glutamate concentration and can be calculated using the Nernst equation:

$\mathrm{E}_{\mathrm{EAAT}}=[\mathrm{RT} / \mathrm{F}(3(\mathrm{Na})+1(\mathrm{H})-1(\mathrm{~K})-1(\mathrm{Glu})]$

$\left.\mathrm{x} \ln \left[3 \ln \left(\left[\mathrm{Na}^{+}\right]_{\mathrm{o}} /\left[\mathrm{Na}^{+}\right]_{\mathrm{i}}\right)+\ln \left(\left[\mathrm{H}^{+}\right]_{\mathrm{o}}\right) /\left[\mathrm{H}^{+}\right]_{\mathrm{i}}\right)+\ln \left(\left[\mathrm{Glu}^{-}\right]_{\mathrm{o}} /\left[\mathrm{Glu}^{-}\right]_{\mathrm{i}}\right)-\ln \left(\left[\mathrm{K}^{+}\right]_{\mathrm{o}} /\left[\mathrm{K}^{+}\right]_{\mathrm{i}}\right)\right]$

In astrocytes, glutamate is degraded by the glutamine synthase resulting in a low glutamate concentration probably not exceeding $0.3 \mathrm{mM}$ [86]; and hence the resting

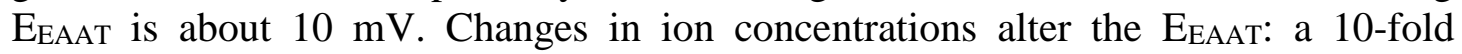
change in $\left[\mathrm{Na}^{+}\right]_{\mathrm{o}}$ shifts the reversal potential by $100 \mathrm{mV}$; 10 -fold changes in [Glu$\left.{ }^{-}\right]_{0}$, $\left[\mathrm{H}^{+}\right]_{\mathrm{o}}$ and $\left[\mathrm{K}^{+}\right]_{\mathrm{o}}$ shift EEAT by 31, 25 and $-31 \mathrm{mV}$ respectively [87].

The operation of EAATs is accompanied with substantial $\mathrm{Na}^{+}$influx which underlies the generation of astroglial $\mathrm{Na}^{+}$signals [34, 48-50, 88]. In addition, the EAAT molecule contains a $\mathrm{Cl}^{-}$channel, which is activated by glutamate transport and which contributes to astroglial $\mathrm{Cl}^{-}$homeostasis [67]. As extracellular glutamate concentration changes in the process of physiological neuronal activity by 5 - 6 orders of magnitude (from low $\mathrm{nM}$ to $\sim \mathrm{mM}$ range), it is glutamate that mostly defines the EЕAAT. At the peak of synaptic transmission when [Glu] exceeds $1 \mathrm{mM}$, the EEAAT is shifted to $+145 \mathrm{mV}$, which ascertains that the transporter always operates in the forward mode. In consequence, in physiological conditions, the stoichiometry of the transporter can support a $\sim 10^{6}$ fold transmembrane glutamate gradient, and can operate as an uptake system even when transmembrane ion gradients for $\mathrm{Na}^{+}$or $\mathrm{K}^{+}$ are seriously disturbed. Although the reversal of EAATs can be achieved in artificial conditions and in the absence of glutamate in the intracellular solution [89]), glutamate release through this route seems to be unlikely in pathology, when extracellular glutamate is high. 


\subsection{Sxc cystine/glutamate antiporter}

The Sxc cystine/glutamate antiporter (Fig. 3) is an important part of both glutamate homeostasis and the intrinsic anti-oxidant defence. The $\mathrm{Sxc}^{-}$is assembled of xCT/SCL7A11 and 4F2hc/SLC3A2 proteins [90]; and in the CNS it is mostly expressed in astrocytes [91-93]. Expression of Sxc is up-regulated by cAMP and by glutathione depletion [94, 95]. The $\mathrm{Scx}^{-}$exchanges extracellular cystine for intracellular glutamate with a $1: 1$ stoichiometry. Import of cystine is critical for astroglial glutathione production; whereas export of glutamate apparently regulates neuronal excitability and synaptic transmission through activation of extrasynaptic neuronal metabotropic glutamate receptors [93].

\section{3. $\mathrm{Na}^{+}$-dependent GABA transporter GAT1 and GAT3}

The main types of CNS sodium-dependent GABA transporters of the SLC6 family are represented by GAT1/SLC6A1 and GAT3/SLC6A11; the expression of betaine/GABA transporter-1 BGT-1/SLC6A12 has been found to be relatively minor $[84,96]$. GAT3 is relatively specific for astrocytes, while GAT1 is considered to be mainly a neuronal transporter, albeit it is also expressed in astroglial cells [97, 98]. GAT3 GABA transporters are concentrated in astroglial perisynaptic membranes covering both symmetric and asymmetric synapses [99, 100].

The operational cycle of GABA uptake involves the co-transport of $\mathrm{Na}^{+}$and $\mathrm{Cl}^{-}$with a stoichiometry $1 \mathrm{GABA}: 2 \mathrm{Na}^{+}: 1 \mathrm{Cl}^{-}$(Fig. 3); this underlies the electrogeneity of the transporter reflecting net influx of a positive charge in the forward mode [101103]. The reversal potential of the transporter $\left(\mathrm{E}_{\mathrm{GAT}}\right)$ lies around $\sim-50 \mathrm{mV}$; which makes is reversible in physiological conditions; indeed relatively small increases in $\left[\mathrm{Na}^{+}\right]_{\mathrm{i}}$ led to a reversal of GABA transport in cortical astrocytes [104].

\subsection{Glycine transporter GlyT1}

Astrocytes in the brain and in the spinal cord specifically express GlyT1/SLC6A9 $\mathrm{Na}^{+}-\mathrm{Cl}^{-}$-dependent glycine transporters (Fig. 3); neurones express GlyT2/SLC6A5 $[105,106]$. The GlyT1 operates with a stoichiometry of 1 Gly : $2 \mathrm{Na}^{+}: 1 \mathrm{Cl}^{-}$[107]. The GlyT1 can reverse in physiological conditions; such a reversal has been characterised in cultured cortical astrocytes [108] and in Bergmann glia in cerebellar slices [109].

\subsection{Adenosine transporters}

Astrocytes specifically express adenosine kinase, an important enzyme of adenosine metabolism [110, 111]. Trans-plasmalemmal transport of adenosine in astrocytes is mediated by two types of transporters: the equilibrative nucleoside transporters ENT1/SLC29A1, ENT-2/SLC29A2, ENT-3/SLC29A3 and ENT-4/SLC29A4, which are controlled solely by the transmembrane gradient for adenosine [112], and by the $\mathrm{Na}^{+}-$ dependent concentrative nucleoside transporters CNT2/SLC28A2 and CNT3/SLC28A3 (Fig. 3). The latter two co-transport adenosine with $1 \mathrm{Na}^{+}$and hence depend on the transmembrane $\mathrm{Na}^{+}$gradient. Concentrative adenosine transporters have been identified in freshly isolated and in cultured astrocytes [113, 114]. 
4.6. Monoamine transporters: noradrenaline transporter NET, dopamine transporter DAT and serotonin transporter SERT

Astrocytes express monoaminoxidase- $\mathrm{B}$, which is the key enzyme for the catabolism of monoamines [115, 116]. Astrocytes are also equipped with plasmalemmal transporters that mediate the accumulation of monoamines. This uptake is $\mathrm{Na}^{+}$ dependent $[117,118]$ and it is accomplished by the operation of the norepinephrine transporter NET/SLC6A2, which co-transports noradrenalin and dopamine together with $2 \mathrm{Na}^{+}$and $1 \mathrm{Cl}^{-}$[119-121] (Fig. 3). There is also some evidence indicating expression of a deducted dopamine transporter DAT/SLC6A3 [122], this transporter is also $\mathrm{Na}^{+}$dependent with a stoichiometry 1 dopamine : $2 \mathrm{Na}^{+}: 1 \mathrm{Cl}^{-}$(all in). Astrocytes in culture were reported to express serotonin transporter SERT/SLC6A4 $[123,124]$; which operates with stoichiometry $1 \operatorname{serotonin}^{+}: 1 \mathrm{Na}^{+}: 1 \mathrm{Cl}^{-}$(in) $: 1 \mathrm{~K}^{+}$ (out) [125].

\section{Neurotransmitter precursor transporters}

\subsection{Glutamine transporters}

Glutamate and GABA (the latter in physiological conditions derives from glutamate through the reaction catalysed by GAD67) are two major neurotransmitters in the CNS, the former mediating excitatory and the latter inhibitory synaptic transmission. Neurones, however, are incapable of synthesising glutamate de novo, and CNS glutamatergic and GABAergic transmission relies on astrocytes that supply neurones with the glutamate precursor glutamine. Glutamine is produced in astrocytes from glutamate (that is either synthesised or directly taken up by glutamate transporters) by the astroglia-specific enzyme glutamine synthetase. Glutamine synthetase, and plasmalemmal transporters for glutamate and glutamine constitute the glutamate(GABA)-glutamine shuttle, the operation of which is obligatory for synaptic transmission utilising glutamate and GABA.

Astroglial glutamine transporters (which are also known as $\mathrm{N}$ system) are represented by the sodium-coupled neutral amino acid transporters SNAT3/SLC38A3 and SNAT5/SLC38A5 (Fig. 4). The stoichiometry of both transporters is 1 Glutamine : 1 $\mathrm{Na}^{+}$(out) $/ 1 \mathrm{H}^{+}$(in); this stipulates electroneutrality of the transporter [126]. An increase in the cytoplasmic $\mathrm{Na}^{+}$concentration stimulates SNAT transporters and hence glutamine efflux [127]; thus astroglial $\mathrm{Na}^{+}$signals evoked by neuronal activity potentiate the supply of neurones with glutamate/GABA precursor. Astroglial glutamine transporters are optimised for the export of glutamine; after being released, glutamine is taken up by neuronal glutamine transporters (system A: SNAT1/SLC38A1, SNAT2/SLC38A2 and SNAT4/SLC38A4), which are specialised for glutamine import. Neuronal glutamine transporters translocate glutamine together with a single molecule of $\mathrm{Na}^{+}$, which makes them electrogenic [128]. Consequently, glutamate transport into neurones results in a depolarisation, which may give glutamate some signalling relevance [129].

\section{2. $L / D$-serine transporters}


D-serine is a positive modulator of NMDA receptors; D-serine was, for a while, considered to be an epitome "gliotransmitter" [130-133]. Recent fact checking however questioned this concept; it seems that most of the enzyme serine racemase that catalyses the synthesis of D-serine is concentrated in neurones [134]. Be this as it may, neurones cannot make D-serine without the assistance from astroglia. The obligatory precursor of D-serine is almost exclusively produced by astrocytes, which express relevant enzymes such as 3-phosphoglycerate dehydrogenase, or Phgdh [135]. Genetic knockout of Phgdh was shown to suppress neuronal synthesis of D-serine by almost 80\% [136]; of note mutations of Phgdh encoding gene cause severe neurodevelopmental deficits [137]. The transmembrane transport of both D- and Lserine is mediated by a neutral amino acid transporter ASCT2/SLC1A5 [138] (Fig. 4). The ASCT2 is a $\mathrm{Na}^{+}$-dependent with a $\mathrm{Na}^{+}$to amino acid stoichiometry of $1: 1$ [139].

\section{Metabolic transporters}

\subsection{Glucose transporters}

Astrocytes are greatly involved in brain metabolism; astrocytes accumulate about $50 \%$ of glucose entering the brain and are the only cells of the CNS capable of synthesising glucagon [140]. Astrocytes accumulate glucose through two distinct transporters. The main type of glucose transporter in astrocytes is GLUT1/SLC2A1 [141] (Fig. 5); this transporter is preferentially concentrated in astroglial perisynaptic processes and endfeet [142]. Glucose transport by GLUT1 is sensitive to neuronal activity and glutamate strongly and rapidly stimulated glucose uptake [143]. In addition, expression of the $\mathrm{Na}^{+}$-dependent glucose transporter SGLT1/SLC5A1 (with cotransports 1 molecule of glucose together with 2 molecules of $\mathrm{Na}^{+}$) has been detected in cultured astroglial cells [144].

\subsection{Monocarboxylate transporters, MCT}

Lactate represents one of the preferred energy substrates for neuronal metabolism; and astrocytes can produce and secrete lactate in concordance with neuronal activity. It appears that increases in $\left[\mathrm{Na}^{+}\right]_{\mathrm{i}}$ that result from $\mathrm{Na}^{+}$-dependent glutamate uptake stimulate aerobic glycolysis thus producing lactate, which is subsequently transported to neurones to support their metabolism [145]. Impairments of astroglial lactate production affect brain plasticity and may cause cognitive deficits [146]. Furthermore, lactate released by astrocytes may potentially act as a signalling molecule contributing to astroglia-neuronal dialogue [147]. Astroglial secretion of lactate is mediated by the plasmalemmal monocarboxylate transporters 1 and 4 (MCT1/SLC16A1, MCT4/SLC16A3), which provide for $\mathrm{H}^{+}$-coupled translocation of lactate (Fig. 5). These two transporters have a different affinity for lactate $\left(\mathrm{K}_{\mathrm{m}}\right.$ for MCT1 $\sim 5 \mathrm{mM}, \mathrm{K}_{\mathrm{m}}$ for MCT4 34 mM; [148]). Astroglial expression of both transporters has been confirmed in vivo [149]. The MCT1/4 are equilibrative transporters and can mediate both import and export of lactate; the transport direction depends on concentrations gradients for monocarboxylate and $\mathrm{H}^{+}$[148].

\subsection{Ascorbic acid transporters}

Astrocytes ensure the production of glutathione and ascorbic acid that are the key elements of the anti-oxidative system of the CNS [150]. Astrocytes are the main depot 
of ascorbic acid [150, 151]. In addition, astrocytes take up dehydroascorbic acid (the end product of ROS oxidation) released from neurones and reduce it to ascorbic acid [152]. Neuronal activity and extracellular glutamate stimulate the astroglial release of ascorbic acid [153]. Cultured astrocytes have been found to express the $\mathrm{Na}^{+}-$ dependent vitamin C transporter SVCT2/SLC23A2, which moves the reduced form of the ascorbic acid with a stoichiometry of $2 \mathrm{Na}^{+}$together with 1 ascorbate [154, 155] (NAAT; Fig. 5). The SVCT2 transporters have been detected in hypothalamic tanycytes in vitro and in situ at transcript and protein levels [156]. NAATs also seem to play a role in brain pathology, focal ischemia induced astroglial expression of SVCT2 [157].

\section{Astroglial $\mathrm{Na}^{+}$signalling couples neuronal activity with homeostatic transporters}

Transporters and pumps dwelling in the plasma membrane of astrocytes are fundamental for their homeostatic function: these transporters provide for ionostasis, homeostasis of neurotransmitters, support of neuronal metabolism and neuroprotection. The majority of these transporters are regulated by the concentration of $\mathrm{Na}^{+}$ions, either directly or indirectly. At the background of a rather high extracellular $\mathrm{Na}^{+}$concentration $(\sim 150 \mathrm{mM})$, relative changes in extracellular $\mathrm{Na}^{+}$ appear rather moderate, e.g. averaging $\sim 2 \mathrm{mM}$ with recurrent network activity in mouse hippocampal slices [158]. Activity-related changes in cytosolic $\mathrm{Na}^{+}$, in contrast, are of much larger with relative magnitude of intracellular $\mathrm{Na}^{+}$changes $\geq 30$ $\%$ with short bursts of activity, see e.g. [50]. Cytosolic $\mathrm{Na}^{+}$therefore exerts a direct control over all $\mathrm{Na}^{+}$dependent transporters (including NKA and SLC transporters) through the transmembrane electrochemical $\mathrm{Na}^{+}$driving force. Cytosolic $\mathrm{Na}^{+}$also indirectly controls other transporters for example influencing cellular metabolism (an increase in $\left[\mathrm{Na}^{+}\right]_{i}$ stimulates lactate production thus increasing MCT-mediated lactate export; $\mathrm{Na}^{+}$-driven reversal of NCX triggers a $\left[\mathrm{Ca}^{2+}\right]_{i}$ increase which stimulates plasmalemmal and ER $\mathrm{Ca}^{2+}$ pumps, etc.).

Neuronal activity or physiological stimulation of astrocytes with mechanical or neurochemical stimuli trigger astroglial $\left[\mathrm{Na}^{+}\right]_{\mathrm{i}}$ transients, which represent the substrate of astroglial $\mathrm{Na}^{+}$signalling that has been conceptualised in recent years [34, $49,159,160]$. Astroglial $\left[\mathrm{Na}^{+}\right]_{\mathrm{i}}$ transients have amplitudes of up to $20 \mathrm{mM}$ and exhibit rather prolonged kinetics; these $\left[\mathrm{Na}^{+}\right]_{\mathrm{i}}$ transients were characterised in astrocytes in vitro and in situ [48, 50,54, 161-163]. Astroglial $\mathrm{Na}^{+}$signalling results from $\mathrm{Na}^{+}$ entry through plasmalemmal channels (such as ionotropic receptors, TRP channels and possibly voltage-gated $\mathrm{Na}^{+}$channels) and plasmalemmal transporters, while recovery of $\left[\mathrm{Na}^{+}\right]_{\mathrm{i}}$ transients is mainly supported by NKA and by NCX operating in reverse mode [34]. In physiological conditions, a prominent pathway for $\mathrm{Na}^{+}$entry is, arguably, associated with EAAT1/2 glutamate transporters [48, 164, 165], which translate neuronal synaptic activity into astroglial $\mathrm{Na}^{+}$signals. In neocortical astrocytes, an additional substantial $\mathrm{Na}^{+}$entry pathway is provided by NMDA receptor channels opening in response to glutamate released from active neurones [51]. Astrocyte $\mathrm{Na}^{+}$signals can spread through propagating $\mathrm{Na}^{+}$waves through $\mathrm{Cx} 30$ or Cx43 containing gap junctions that organise astroglial syncytia [166]. Cellular effectors (or "sensors") of $\mathrm{Na}^{+}$ions are plasmalemmal transporters, several types of plasmalemmal channels (for example $\mathrm{K}_{\mathrm{ir}} 4.1$ channels or VRAC channels), metabotropic receptors $\left(\mathrm{Na}^{+}\right.$ions facilitate dissociation of G-proteins) and enzymes $\left(\mathrm{Na}^{+}\right.$ions for example regulate glutamine synthetase and various metabolic pathways; 
for a recent discussion on $\mathrm{Na}^{+}$-sensors see [14, 34]. Spatio-temporally organised fluctuations in cytosolic $\mathrm{Na}^{+}$concentration may thus represent a $\mathrm{Na}^{+}$signalling system which not only coordinates astroglial physiology, but also glial homoeostatic support and thereby neuronal activity.

\section{Conclusions}

Homeostatic function of astroglia is supported by numerous plasmalemmal transporters. Functional activity of these transporters is mainly regulated by spatiotemporally organised fluctuations in cytosolic $\mathrm{Na}^{+}$concentration that represent a $\mathrm{Na}^{+}$ signalling system which coordinates neuronal activity and glial homoeostatic support. 


\section{References}

[1] H. Kettenmann, B.R. Ransom, Neuroglia, Oxford University Press, Oxford, 2013, pp. 864.

[2] A. Verkhratsky, A.M. Butt, Glial Physiology and Pathophysiology, WileyBlackwell, Chichester, 2013.

[3] L. Hertz, Y. Chen, Importance of astrocytes for potassium ion $\left(\mathrm{K}^{+}\right)$homeostasis in brain and glial effects of $\mathrm{K}^{+}$and its transporters on learning, Neurosci Biobehav Rev, 71 (2016) 484-505.

[4] A. Verkhratsky, M. Nedergaard, L. Hertz, Why are astrocytes important?, Neurochem Res, 40 (2015) 389-401.

[5] M.E. Gibbs, D. Hutchinson, L. Hertz, Astrocytic involvement in learning and memory consolidation, Neurosci Biobehav Rev, 32 (2008) 927-944.

[6] A.M. Butt, N. Hamilton, P. Hubbard, M. Pugh, M. Ibrahim, Synantocytes: the fifth element, J Anat, 207 (2005) 695-706.

[7] A. Nishiyama, R. Suzuki, X. Zhu, NG2 cells (polydendrocytes) in brain physiology and repair, Front Neurosci, 8 (2014) 133.

[8] J.C. Savage, K. Picard, F. Gonzalez-Ibanez, M.E. Tremblay, A Brief History of Microglial Ultrastructure: Distinctive Features, Phenotypes, and Functions Discovered Over the Past 60 Years by Electron Microscopy, Front Immunol, 9 (2018) 803.

[9] M.E. Tremblay, C. Lecours, L. Samson, V. Sanchez-Zafra, A. Sierra, From the Cajal alumni Achucarro and Rio-Hortega to the rediscovery of never-resting microglia, Front Neuroanat, 9 (2015) 45.

[10] M.E. Tremblay, B. Stevens, A. Sierra, H. Wake, A. Bessis, A. Nimmerjahn, The role of microglia in the healthy brain, J Neurosci, 31 (2011) 16064-16069.

[11] H. Kettenmann, U.K. Hanisch, M. Noda, A. Verkhratsky, Physiology of microglia, Physiol Rev, 91 (2011) 461-553.

[12] M. Bradl, H. Lassmann, Oligodendrocytes: biology and pathology, Acta Neuropathol, 119 (2010) 37-53.

[13] K.A. Nave, H.B. Werner, Myelination of the nervous system: mechanisms and functions, Annu Rev Cell Dev Biol, 30 (2014) 503-533.

[14] A. Verkhratsky, M. Nedergaard, Physiology of Astroglia, Physiol Rev, 98 (2018) 239-389.

[15] J.A. Colombo, H.D. Reisin, Interlaminar astroglia of the cerebral cortex: a marker of the primate brain, Brain Res, 1006 (2004) 126-131.

[16] J.A. Colombo, A. Yanez, V. Puissant, S. Lipina, Long, interlaminar astroglial cell processes in the cortex of adult monkeys, J Neurosci Res, 40 (1995) 551-556.

[17] A. Verkhratsky, N.A. Oberheim Bush, M. Nedergaard, A. Butt, The Special Case of Human Astrocytes

Neuroglia, 1 ( 2018) 4.

[18] A. Verkhratsky, M. Nedergaard, Astroglial cradle in the life of the synapse,

Philos Trans R Soc Lond B Biol Sci, 369 (2014) 20130595.

[19] M. Nedergaard, A. Verkhratsky, Artifact versus reality--how astrocytes

contribute to synaptic events, Glia, 60 (2012) 1013-1023.

[20] B.S. Khakh, B. Deneen, The Emerging Nature of Astrocyte Diversity, Annu Rev Neurosci, 42 (2019) 187-207.

[21] P. Bedner, R. Jabs, C. Steinhauser, Properties of human astrocytes and NG2 glia, Glia, (2019). 
[22] L. Ben Haim, D.H. Rowitch, Functional diversity of astrocytes in neural circuit regulation, Nat Rev Neurosci, 18 (2017) 31-41.

[23] B.S. Khakh, Astrocyte-Neuron Interactions in the Striatum: Insights on Identity, Form, and Function, Trends Neurosci, 42 (2019) 617-630.

[24] J.D. Cahoy, B. Emery, A. Kaushal, L.C. Foo, J.L. Zamanian, K.S.

Christopherson, Y. Xing, J.L. Lubischer, P.A. Krieg, S.A. Krupenko, W.J. Thompson, B.A. Barres, A transcriptome database for astrocytes, neurons, and oligodendrocytes: a new resource for understanding brain development and function, J Neurosci, 28 (2008) 264-278.

[25] D. Lovatt, U. Sonnewald, H.S. Waagepetersen, A. Schousboe, W. He, J.H. Lin, X. Han, T. Takano, S. Wang, F.J. Sim, S.A. Goldman, M. Nedergaard, The transcriptome and metabolic gene signature of protoplasmic astrocytes in the adult murine cortex, J Neurosci, 27 (2007) 12255-12266.

[26] D.G. Nicholls, S.J. Ferguson, Bioenergetics, Academic Press/Elsevier, Amsterdam etc., 2013.

[27] M.V. Clausen, F. Hilbers, H. Poulsen, The Structure and Function of the Na,KATPase Isoforms in Health and Disease, Front Physiol, 8 (2017) 371.

[28] G. Blanco, R.W. Mercer, Isozymes of the Na-K-ATPase: heterogeneity in structure, diversity in function, Am J Physiol, 275 (1998) F633-650.

[29] M. Juhaszova, M.P. Blaustein, $\mathrm{Na}^{+}$pump low and high ouabain affinity alpha subunit isoforms are differently distributed in cells, Proc Natl Acad Sci U S A, 94 (1997) 1800-1805.

[30] M. Melone, C. Ciriachi, D. Pietrobon, F. Conti, Heterogeneity of Astrocytic and Neuronal GLT-1 at Cortical Excitatory Synapses, as Revealed by its Colocalization With $\mathrm{Na}^{+} / \mathrm{K}^{+}$-ATPase $\alpha$ Isoforms, Cereb Cortex, (2018).

[31] B.R. Larsen, M. Assentoft, M.L. Cotrina, S.Z. Hua, M. Nedergaard, K. Kaila, J. Voipio, N. MacAulay, Contributions of the $\mathrm{Na}^{+} / \mathrm{K}^{+}$-ATPase, NKCC1, and $\mathrm{K}_{\mathrm{ir}} 4.1$ to hippocampal $\mathrm{K}^{+}$clearance and volume responses, Glia, 62 (2014) 608-622.

[32] I. Hajek, K.V. Subbarao, L. Hertz, Acute and chronic effects of potassium and noradrenaline on $\mathrm{Na}^{+}, \mathrm{K}^{+}$-ATPase activity in cultured mouse neurons and astrocytes, Neurochem Int, 28 (1996) 335-342.

[33] L. Hertz, N.J. Gerkau, J. Xu, S. Durry, D. Song, C.R. Rose, L. Peng, Roles of astrocytic $\mathrm{Na}^{+}, \mathrm{K}^{+}$-ATPase and glycogenolysis for $\mathrm{K}^{+}$homeostasis in mammalian brain, J Neurosci Res, 93 (2015) 1019-1030.

[34] C.R. Rose, A. Verkhratsky, Principles of sodium homeostasis and sodium signalling in astroglia, Glia, 64 (2016) 1611-1627.

[35] C. Capuani, M. Melone, A. Tottene, L. Bragina, G. Crivellaro, M. Santello, G. Casari, F. Conti, D. Pietrobon, Defective glutamate and $\mathrm{K}^{+}$clearance by cortical astrocytes in familial hemiplegic migraine type 2, EMBO Mol Med, 8 (2016) 967986.

[36] A. Verkhratsky, R.K. Orkand, H. Kettenmann, Glial calcium: homeostasis and signaling function, Physiol Rev, 78 (1998) 99-141.

[37] A. Verkhratsky, J.J. Rodriguez, V. Parpura, Calcium signalling in astroglia, Mol Cell Endocrinol, 353 (2012) 45-56.

[38] M. Brini, E. Carafoli, The plasma membrane $\mathrm{Ca}^{2+}$ ATPase and the plasma membrane sodium calcium exchanger cooperate in the regulation of cell calcium, Cold Spring Harb Perspect Biol, 3 (2011).

[39] L. Fresu, A. Dehpour, A.A. Genazzani, E. Carafoli, D. Guerini, Plasma membrane calcium ATPase isoforms in astrocytes, Glia, 28 (1999) 150-155. 
[40] M. Morita, Y. Kudo, Growth factors upregulate astrocyte $\left[\mathrm{Ca}^{2+}\right]_{i}$ oscillation by increasing SERCA2b expression, Glia, 58 (2010) 1988-1995.

[41] C.A. Pappas, B.R. Ransom, A depolarization-stimulated, bafilomycin-inhibitable $\mathrm{H}^{+}$pump in hippocampal astrocytes, Glia, 9 (1993) 280-291.

[42] J.M. Philippe, J.M. Dubois, B. Rouzaire-Dubois, P.F. Cartron, F. Vallette, N. Morel, Functional expression of V-ATPases in the plasma membrane of glial cells, Glia, 37 (2002) 365-373.

[43] A. Verkhratsky, M. Trebak, F. Perocchi, D. Khananshvili, I. Sekler, Crosslink between calcium and sodium signalling, Exp Physiol, 103 (2018) 157-169.

[44] J. Lytton, $\mathrm{Na}^{+} / \mathrm{Ca}^{2+}$ exchangers: three mammalian gene families control $\mathrm{Ca}^{2+}$ transport, Biochem J, 406 (2007) 365-382.

[45] L.W. Pappalardo, O.A. Samad, J.A. Black, S.G. Waxman, Voltage-gated sodium channel $\mathrm{Na}_{\mathrm{v}} 1.5$ contributes to astrogliosis in an in vitro model of glial injury via reverse $\mathrm{Na}^{+} / \mathrm{Ca}^{2+}$ exchange, Glia, 62 (2014) 1162-1175.

[46] M.P. Blaustein, M. Juhaszova, V.A. Golovina, P.J. Church, E.F. Stanley, Na/Ca exchanger and PMCA localization in neurons and astrocytes: functional implications, Ann N Y Acad Sci, 976 (2002) 356-366.

[47] A. Minelli, P. Castaldo, P. Gobbi, S. Salucci, S. Magi, S. Amoroso, Cellular and subcellular localization of $\mathrm{Na}^{+}-\mathrm{Ca}^{2+}$ exchanger protein isoforms, NCX1, NCX2, and NCX3 in cerebral cortex and hippocampus of adult rat, Cell Calcium, 41 (2007) 221234.

[48] S. Kirischuk, H. Kettenmann, A. Verkhratsky, Membrane currents and cytoplasmic sodium transients generated by glutamate transport in Bergmann glial cells, Pflugers Arch, 454 (2007) 245-252.

[49] S. Kirischuk, V. Parpura, A. Verkhratsky, Sodium dynamics: another key to astroglial excitability?, Trends Neurosci, 35 (2012) 497-506.

[50] J. Langer, C.R. Rose, Synaptically induced sodium signals in hippocampal astrocytes in situ, J Physiol, 587 (2009) 5859-5877.

[51] D. Ziemens, F. Oschmann, N.J. Gerkau, C.R. Rose, Heterogeneity of ActivityInduced Sodium Transients between Astrocytes of the Mouse Hippocampus and Neocortex: Mechanisms and Consequences, J Neurosci, 39 (2019) 2620-2634.

[52] M.P. Blaustein, W.F. Goldman, G. Fontana, B.K. Krueger, E.M. Santiago, T.D. Steele, D.N. Weiss, P.J. Yarowsky, Physiological roles of the sodium-calcium exchanger in nerve and muscle, Ann N Y Acad Sci, 639 (1991) 254-274.

[53] M.P. Blaustein, W.J. Lederer, Sodium/calcium exchange: its physiological implications, Physiol Rev, 79 (1999) 763-854.

[54] S. Kirischuk, H. Kettenmann, A. Verkhratsky, $\mathrm{Na}^{+} / \mathrm{Ca}^{2+}$ exchanger modulates kainate-triggered $\mathrm{Ca}^{2+}$ signaling in Bergmann glial cells in situ, FASEB J, 11 (1997) 566-572.

[55] E. Turovsky, S.M. Theparambil, V. Kasymov, J.W. Deitmer, A.G. Del Arroyo, G.L. Ackland, J.J. Corneveaux, A.N. Allen, M.J. Huentelman, S. Kasparov, N.

Marina, A.V. Gourine, Mechanisms of $\mathrm{CO}_{2} / \mathrm{H}^{+}$Sensitivity of Astrocytes, J Neurosci, 36 (2016) 10750-10758.

[56] K. Takuma, T. Matsuda, H. Hashimoto, S. Asano, A. Baba, Cultured rat astrocytes possess $\mathrm{Na}^{+}-\mathrm{Ca}^{2+}$ exchanger, Glia, 12 (1994) 336-342.

[57] K. Takuma, T. Matsuda, H. Hashimoto, J. Kitanaka, S. Asano, Y. Kishida, A. Baba, Role of $\mathrm{Na}^{+}-\mathrm{Ca}^{2+}$ exchanger in agonist-induced $\mathrm{Ca}^{2+}$ signaling in cultured rat astrocytes, J Neurochem, 67 (1996) 1840-1845.

[58] V. Parpura, A. Verkhratsky, Homeostatic function of astrocytes: $\mathrm{Ca}^{2+}$ and $\mathrm{Na}^{+}$ signalling, Transl Neurosci, 3 (2012) 334-344. 
[59] J.J. Wade, K. Breslin, K. Wong-Lin, J. Harkin, B. Flanagan, H. Van Zalinge, S. Hall, M. Dallas, A. Bithell, A. Verkhratsky, L. McDaid, Calcium Microdomain Formation at the Perisynaptic Cradle Due to NCX Reversal: A Computational Study, Front Cell Neurosci, 13 (2019) 185.

[60] N. Macaulay, T. Zeuthen, Glial $\mathrm{K}^{+}$clearance and cell swelling: key roles for cotransporters and pumps, Neurochem Res, 37 (2012) 2299-2309.

[61] C. Kanaka, K. Ohno, A. Okabe, K. Kuriyama, T. Itoh, A. Fukuda, K. Sato, The differential expression patterns of messenger RNAs encoding $\mathrm{K}-\mathrm{Cl}$ cotransporters $(\mathrm{KCC} 1,2)$ and $\mathrm{Na}-\mathrm{K}-2 \mathrm{Cl}$ cotransporter (NKCC1) in the rat nervous system, Neuroscience, 104 (2001) 933-946.

[62] B.A. MacVicar, D. Feighan, A. Brown, B. Ransom, Intrinsic optical signals in the rat optic nerve: role for $\mathrm{K}^{+}$uptake via NKCC1 and swelling of astrocytes, Glia, 37 (2002) 114-123.

[63] T.J. Price, K.M. Hargreaves, F. Cervero, Protein expression and mRNA cellular distribution of the NKCC1 cotransporter in the dorsal root and trigeminal ganglia of the rat, Brain Res, 1112 (2006) 146-158.

[64] G. Su, R.A. Haworth, R.J. Dempsey, D. Sun, Regulation of $\mathrm{Na}^{+}-\mathrm{K}^{+}-\mathrm{Cl}^{-}$ cotransporter in primary astrocytes by dibutyryl cAMP and high $\left[\mathrm{K}^{+}\right]_{\mathrm{o}}$, Am J Physiol Cell Physiol, 279 (2000) C1710-1721.

[65] G. Su, D.B. Kintner, M. Flagella, G.E. Shull, D. Sun, Astrocytes from $\mathrm{Na}^{+}-\mathrm{K}^{+}-$ $\mathrm{Cl}^{-}$cotransporter-null mice exhibit absence of swelling and decrease in EAA release, Am J Physiol Cell Physiol, 282 (2002) C1147-1160.

[66] G. Su, D.B. Kintner, D. Sun, Contribution of $\mathrm{Na}^{+}-\mathrm{K}^{+}-\mathrm{Cl}^{-}$cotransporter to high$\left[\mathrm{K}^{+}\right]_{0^{-}}$induced swelling and EAA release in astrocytes, Am J Physiol Cell Physiol, 282 (2002) C1136-1146.

[67] V. Untiet, P. Kovermann, N.J. Gerkau, T. Gensch, C.R. Rose, C. Fahlke, Glutamate transporter-associated anion channels adjust intracellular chloride concentrations during glial maturation, Glia, 65 (2017) 388-400.

[68] A.B. Steffensen, E.K. Oernbo, A. Stoica, N.J. Gerkau, D. Barbuskaite, K. Tritsaris, C.R. Rose, N. MacAulay, Cotransporter-mediated water transport underlying cerebrospinal fluid formation, Nat Commun, 9 (2018) 2167.

[69] F. Ringel, N. Plesnila, Expression and functional role of potassium-chloride cotransporters (KCC) in astrocytes and C6 glioma cells, Neurosci Lett, 442 (2008) 219-223.

[70] M. Chesler, Regulation and modulation of $\mathrm{pH}$ in the brain, Physiol Rev, 83 (2003) 1183-1221.

[71] J.W. Deitmer, C.R. Rose, pH regulation and proton signalling by glial cells, Prog Neurobiol, 48 (1996) 73-103.

[72] J. Orlowski, S. Grinstein, $\mathrm{Na}^{+} / \mathrm{H}^{+}$exchangers of mammalian cells, J Biol Chem, 272 (1997) 22373-22376.

[73] E.A. Newman, Acid efflux from retinal glial cells generated by sodium bicarbonate cotransport, J Neurosci, 16 (1996) 159-168.

[74] N. Brookes, R.J. Turner, $\mathrm{K}^{+}$-induced alkalinization in mouse cerebral astrocytes mediated by reversal of electrogenic $\mathrm{Na}^{+}-\mathrm{HCO}_{3}{ }^{-}$cotransport, Am J Physiol, 267 (1994) C1633-1640.

[75] S.M. Theparambil, Z. Naoshin, A. Thyssen, J.W. Deitmer, Reversed electrogenic sodium bicarbonate cotransporter 1 is the major acid loader during recovery from cytosolic alkalosis in mouse cortical astrocytes, J Physiol, 593 (2015) 3533-3547. 
[76] E.R. O'Connor, H. Sontheimer, B.R. Ransom, Rat hippocampal astrocytes exhibit electrogenic sodium-bicarbonate co-transport, J Neurophysiol, 72 (1994) 2580-2589.

[77] I.I. Grichtchenko, M. Chesler, Depolarization-induced alkalinization of astrocytes in gliotic hippocampal slices, Neuroscience, 62 (1994) 1071-1078.

[78] T. Storck, S. Schulte, K. Hofmann, W. Stoffel, Structure, expression, and functional analysis of a $\mathrm{Na}^{+}$-dependent glutamate/aspartate transporter from rat brain, Proc Natl Acad Sci U S A, 89 (1992) 10955-10959.

[79] G. Pines, N.C. Danbolt, M. Bjoras, Y. Zhang, A. Bendahan, L. Eide, H. Koepsell, J. Storm-Mathisen, E. Seeberg, B.I. Kanner, Cloning and expression of a rat brain L-glutamate transporter, Nature, 360 (1992) 464-467.

[80] R.J. Vandenberg, R.M. Ryan, Mechanisms of glutamate transport, Physiol Rev, 93 (2013) 1621-1657.

[81] U.V. Berger, M.A. Hediger, Distribution of the glutamate transporters GLAST and GLT-1 in rat circumventricular organs, meninges, and dorsal root ganglia, $\mathrm{J}$ Comp Neurol, 421 (2000) 385-399.

[82] K.P. Lehre, N.C. Danbolt, The number of glutamate transporter subtype molecules at glutamatergic synapses: chemical and stereological quantification in young adult rat brain, J Neurosci, 18 (1998) 8751-8757.

[83] T. Rauen, J.D. Rothstein, H. Wassle, Differential expression of three glutamate transporter subtypes in the rat retina, Cell Tissue Res, 286 (1996) 325-336.

[84] Y. Zhou, N.C. Danbolt, GABA and glutamate transporters in brain, Front Endocrinol (Lausanne), 4 (2013) 165.

[85] F.A. Chaudhry, K.P. Lehre, M. van Lookeren Campagne, O.P. Ottersen, N.C. Danbolt, J. Storm-Mathisen, Glutamate transporters in glial plasma membranes: highly differentiated localizations revealed by quantitative ultrastructural immunocytochemistry, Neuron, 15 (1995) 711-720.

[86] C.R. Bramham, R. Torp, N. Zhang, J. Storm-Mathisen, O.P. Ottersen, Distribution of glutamate-like immunoreactivity in excitatory hippocampal pathways: a semiquantitative electron microscopic study in rats, Neuroscience, 39 (1990) 405417.

[87] N. Zerangue, M.P. Kavanaugh, Flux coupling in a neuronal glutamate transporter, Nature, 383 (1996) 634-637.

[88] A. Verkhratsky, V. Untiet, C.R. Rose, Ionic signalling in astroglia beyond calcium, J Physiol, (2019).

[89] M. Szatkowski, B. Barbour, D. Attwell, Non-vesicular release of glutamate from glial cells by reversed electrogenic glutamate uptake, Nature, 348 (1990) 443-446.

[90] S. Broer, C.A. Wagner, Structure-function relationships of heterodimeric amino acid transporters, Cell Biochem Biophys, 36 (2002) 155-168.

[91] Y. Cho, S. Bannai, Uptake of glutamate and cysteine in C-6 glioma cells and in cultured astrocytes, J Neurochem, 55 (1990) 2091-2097.

[92] S. Kato, S. Ishita, K. Sugawara, K. Mawatari, Cystine/glutamate antiporter expression in retinal Muller glial cells: implications for DL- $\alpha$-aminoadipate toxicity, Neuroscience, 57 (1993) 473-482.

[93] K. Moussawi, A. Riegel, S. Nair, P.W. Kalivas, Extracellular glutamate: functional compartments operate in different concentration ranges, Front Syst Neurosci, 5 (2011) 94.

[94] G.E. Gochenauer, M.B. Robinson, Dibutyryl-cAMP (dbcAMP) up-regulates astrocytic chloride-dependent L-[3H]glutamate transport and expression of both system xc(-) subunits, J Neurochem, 78 (2001) 276-286. 
[95] T.M. Seib, S.A. Patel, R.J. Bridges, Regulation of the system x(C)cystine/glutamate exchanger by intracellular glutathione levels in rat astrocyte primary cultures, Glia, 59 (2011) 1387-1401.

[96] A. Scimemi, Structure, function, and plasticity of GABA transporters, Front Cell Neurosci, 8 (2014) 161.

[97] F. Conti, A. Minelli, M. Melone, GABA transporters in the mammalian cerebral cortex: localization, development and pathological implications, Brain Res Brain Res Rev, 45 (2004) 196-212.

[98] K.K. Madsen, H.S. White, A. Schousboe, Neuronal and non-neuronal GABA transporters as targets for antiepileptic drugs, Pharmacol Ther, 125 (2010) 394-401. [99] A. Minelli, S. DeBiasi, N.C. Brecha, L.V. Zuccarello, F. Conti, GAT-3, a highaffinity GABA plasma membrane transporter, is localized to astrocytic processes, and it is not confined to the vicinity of GABAergic synapses in the cerebral cortex, $\mathrm{J}$ Neurosci, 16 (1996) 6255-6264.

[100] C.E. Ribak, W.M. Tong, N.C. Brecha, GABA plasma membrane transporters, GAT-1 and GAT-3, display different distributions in the rat hippocampus, J Comp Neurol, 367 (1996) 595-606.

[101] M.P. Kavanaugh, J.L. Arriza, R.A. North, S.G. Amara, Electrogenic uptake of $\gamma$-aminobutyric acid by a cloned transporter expressed in Xenopus oocytes, J Biol Chem, 267 (1992) 22007-22009.

[102] C.C. Lu, D.W. Hilgemann, GAT1 (GABA: $\left.\mathrm{Na}^{+}: \mathrm{Cl}^{-}\right)$cotransport function. Steady state studies in giant Xenopus oocyte membrane patches, J Gen Physiol, 114 (1999) 429-444.

[103] R. Radian, B.I. Kanner, Stoichiometry of sodium- and chloride-coupled gamma-aminobutyric acid transport by synaptic plasma membrane vesicles isolated from rat brain, Biochemistry, 22 (1983) 1236-1241.

[104] P. Unichenko, O. Myakhar, S. Kirischuk, Intracellular $\mathrm{Na}^{+}$concentration influences short-term plasticity of glutamate transporter-mediated currents in neocortical astrocytes, Glia, 60 (2012) 605-614.

[105] V. Eulenburg, W. Armsen, H. Betz, J. Gomeza, Glycine transporters: essential regulators of neurotransmission, Trends Biochem Sci, 30 (2005) 325-333.

[106] F. Zafra, C. Aragon, L. Olivares, N.C. Danbolt, C. Gimenez, J. Storm-Mathisen, Glycine transporters are differentially expressed among CNS cells, J Neurosci, 15 (1995) 3952-3969.

[107] M.J. Roux, S. Supplisson, Neuronal and glial glycine transporters have different stoichiometries, Neuron, 25 (2000) 373-383.

[108] K. Shibasaki, N. Hosoi, R. Kaneko, M. Tominaga, K. Yamada, Glycine release from astrocytes via functional reversal of GlyT1, J Neurochem, (2016).

[109] H. Huang, L. Barakat, D. Wang, A. Bordey, Bergmann glial GlyT1 mediates glycine uptake and release in mouse cerebellar slices, J Physiol, 560 (2004) 721-736. [110] D. Boison, Adenosine as a neuromodulator in neurological diseases, Curr Opin Pharmacol, 8 (2008) 2-7.

[111] D. Boison, J.F. Chen, B.B. Fredholm, Adenosine signaling and function in glial cells, Cell Death Differ, 17 (2010) 1071-1082.

[112] A.E. King, M.A. Ackley, C.E. Cass, J.D. Young, S.A. Baldwin, Nucleoside transporters: from scavengers to novel therapeutic targets, Trends Pharmacol Sci, 27 (2006) 416-425.

[113] B. Li, L. Gu, L. Hertz, L. Peng, Expression of nucleoside transporter in freshly isolated neurons and astrocytes from mouse brain, Neurochem Res, 38 (2013) 23512358. 
[114] L. Peng, R. Huang, A.C. Yu, K.Y. Fung, M.P. Rathbone, L. Hertz, Nucleoside transporter expression and function in cultured mouse astrocytes, Glia, 52 (2005) 2535.

[115] J. Ekblom, S.S. Jossan, M. Bergstrom, L. Oreland, E. Walum, S.M. Aquilonius, Monoamine oxidase-B in astrocytes, Glia, 8 (1993) 122-132.

[116] J.K. Mallajosyula, D. Kaur, S.J. Chinta, S. Rajagopalan, A. Rane, D.G.

Nicholls, D.A. Di Monte, H. Macarthur, J.K. Andersen, MAO-B elevation in mouse brain astrocytes results in Parkinson's pathology, PLoS One, 3 (2008) e1616.

[117] E.W. Pelton, 2nd, H.K. Kimelberg, S.V. Shipherd, R.S. Bourke, Dopamine and norepinephrine uptake and metabolism by astroglial cells in culture, Life Sci, 28 (1981) 1655-1663.

[118] D. Semenoff, H.K. Kimelberg, Autoradiography of high affinity uptake of catecholamines by primary astrocyte cultures, Brain Res, 348 (1985) 125-136. [119] M. Inazu, H. Takeda, T. Matsumiya, Functional expression of the norepinephrine transporter in cultured rat astrocytes, J Neurochem, 84 (2003) 136144.

[120] S. Schroeter, S. Apparsundaram, R.G. Wiley, L.H. Miner, S.R. Sesack, R.D. Blakely, Immunolocalization of the cocaine- and antidepressant-sensitive lnorepinephrine transporter, J Comp Neurol, 420 (2000) 211-232.

[121] H. Takeda, M. Inazu, T. Matsumiya, Astroglial dopamine transport is mediated by norepinephrine transporter, Naunyn Schmiedebergs Arch Pharmacol, 366 (2002) 620-623.

[122] S. Karakaya, M. Kipp, C. Beyer, Oestrogen regulates the expression and function of dopamine transporters in astrocytes of the nigrostriatal system, $\mathrm{J}$ Neuroendocrinol, 19 (2007) 682-690.

[123] M. Inazu, H. Takeda, H. Ikoshi, M. Sugisawa, Y. Uchida, T. Matsumiya, Pharmacological characterization and visualization of the glial serotonin transporter, Neurochem Int, 39 (2001) 39-49.

[124] S. Malynn, A. Campos-Torres, P. Moynagh, J. Haase, The pro-inflammatory cytokine TNF-alpha regulates the activity and expression of the serotonin transporter (SERT) in astrocytes, Neurochem Res, 38 (2013) 694-704.

[125] K. Schicker, Z. Uzelac, J. Gesmonde, S. Bulling, T. Stockner, M. Freissmuth, S. Boehm, G. Rudnick, H.H. Sitte, W. Sandtner, Unifying concept of serotonin transporter-associated currents, J Biol Chem, 287 (2012) 438-445.

[126] M. Scalise, L. Pochini, M. Galluccio, C. Indiveri, Glutamine transport. From energy supply to sensing and beyond, Biochim Biophys Acta, (2016).

[127] A.C. Todd, M.C. Marx, S.R. Hulme, S. Broer, B. Billups, SNAT3-mediated glutamine transport in perisynaptic astrocytes in situ is regulated by intracellular sodium, Glia, (2017).

[128] S. Broer, The SLC38 family of sodium-amino acid co-transporters, Pflugers Arch, 466 (2014) 155-172.

[129] D.A. Rusakov, Astroglial glutamate transporters trigger glutaminergic gliotransmission, J Physiol, 590 (2012) 2187-2188.

[130] M.J. Schell, R.O. Brady, Jr., M.E. Molliver, S.H. Snyder, D-serine as a neuromodulator: regional and developmental localizations in rat brain glia resemble NMDA receptors, J Neurosci, 17 (1997) 1604-1615.

[131] M.J. Schell, M.E. Molliver, S.H. Snyder, D-serine, an endogenous synaptic modulator: localization to astrocytes and glutamate-stimulated release, Proc Natl Acad Sci U S A, 92 (1995) 3948-3952. 
[132] H. Wolosker, S. Blackshaw, S.H. Snyder, Serine racemase: a glial enzyme synthesizing D-serine to regulate glutamate-N-methyl-D-aspartate neurotransmission, Proc Natl Acad Sci U S A, 96 (1999) 13409-13414.

[133] C. Henneberger, T. Papouin, S.H. Oliet, D.A. Rusakov, Long-term potentiation depends on release of D-serine from astrocytes, Nature, 463 (2010) 232-236.

[134] H. Wolosker, D.T. Balu, J.T. Coyle, The rise and fall of the d-serine-mediated gliotransmission hypothesis, Trends Neurosci, 39 (2016) 712-721.

[135] M. Yamasaki, K. Yamada, S. Furuya, J. Mitoma, Y. Hirabayashi, M. Watanabe, 3-Phosphoglycerate dehydrogenase, a key enzyme for l-serine biosynthesis, is preferentially expressed in the radial glia/astrocyte lineage and olfactory ensheathing glia in the mouse brain, J Neurosci, 21 (2001) 7691-7704.

[136] J.H. Yang, A. Wada, K. Yoshida, Y. Miyoshi, T. Sayano, K. Esaki, M.O. Kinoshita, S. Tomonaga, N. Azuma, M. Watanabe, K. Hamase, K. Zaitsu, T. Machida, A. Messing, S. Itohara, Y. Hirabayashi, S. Furuya, Brain-specific Phgdh deletion reveals a pivotal role for L-serine biosynthesis in controlling the level of Dserine, an N-methyl-D-aspartate receptor co-agonist, in adult brain, J Biol Chem, 285 (2010) 41380-41390.

[137] L.W. Klomp, T.J. de Koning, H.E. Malingre, E.A. van Beurden, M. Brink, F.L. Opdam, M. Duran, J. Jaeken, M. Pineda, L. Van Maldergem, B.T. Poll-The, I.E. van den Berg, R. Berger, Molecular characterization of 3-phosphoglycerate dehydrogenase deficiency--a neurometabolic disorder associated with reduced Lserine biosynthesis, Am J Hum Genet, 67 (2000) 1389-1399.

[138] M. Martineau, V. Parpura, J.P. Mothet, Cell-type specific mechanisms of Dserine uptake and release in the brain, Front Synaptic Neurosci, 6 (2014) 12.

[139] C. Maucler, P. Pernot, N. Vasylieva, L. Pollegioni, S. Marinesco, In vivo Dserine hetero-exchange through alanine-serine-cysteine (ASC) transporters detected by microelectrode biosensors, ACS Chem Neurosci, 4 (2013) 772-781.

[140] M. Kreft, L.K. Bak, H.S. Waagepetersen, A. Schousboe, Aspects of astrocyte energy metabolism, amino acid neurotransmitter homoeostasis and metabolic compartmentation, ASN Neuro, 4 (2012).

[141] A. Allen, C. Messier, Plastic changes in the astrocyte GLUT1 glucose transporter and beta-tubulin microtubule protein following voluntary exercise in mice, Behav Brain Res, 240 (2013) 95-102.

[142] S. Morgello, R.R. Uson, E.J. Schwartz, R.S. Haber, The human blood-brain barrier glucose transporter (GLUT1) is a glucose transporter of gray matter astrocytes, Glia, 14 (1995) 43-54.

[143] A. Loaiza, O.H. Porras, L.F. Barros, Glutamate triggers rapid glucose transport stimulation in astrocytes as evidenced by real-time confocal microscopy, J Neurosci, 23 (2003) 7337-7342.

[144] C. Vega, J. R. Sachleben L, D. Gozal, E. Gozal, Differential metabolic adaptation to acute and long-term hypoxia in rat primary cortical astrocytes, J Neurochem, 97 (2006) 872-883.

[145] L. Pellerin, P.J. Magistretti, Sweet sixteen for ANLS, J Cereb Blood Flow Metab, 32 (2012) 1152-1166.

[146] C. Cali, A. Tauffenberger, P. Magistretti, The Strategic Location of Glycogen and Lactate: From Body Energy Reserve to Brain Plasticity, Front Cell Neurosci, 13 (2019) 82.

[147] M. DiNuzzo, Astrocyte-neuron interactions during learning may occur by lactate signaling rather than metabolism, Front Integr Neurosci, 10 (2016) 2. 
[148] A.P. Halestrap, The monocarboxylate transporter family - Structure and functional characterization, IUBMB Life, 64 (2012) 1-9.

[149] A. Rafiki, J.L. Boulland, A.P. Halestrap, O.P. Ottersen, L. Bergersen, Highly differential expression of the monocarboxylate transporters MCT2 and MCT4 in the developing rat brain, Neuroscience, 122 (2003) 677-688.

[150] T.K. Makar, M. Nedergaard, A. Preuss, A.S. Gelbard, A.S. Perumal, A.J. Cooper, Vitamin E, ascorbate, glutathione, glutathione disulfide, and enzymes of glutathione metabolism in cultures of chick astrocytes and neurons: evidence that astrocytes play an important role in antioxidative processes in the brain, J Neurochem, 62 (1994) 45-53.

[151] A. Covarrubias-Pinto, A.I. Acuna, F.A. Beltran, L. Torres-Diaz, M.A. Castro, Old things new view: Ascorbic acid protects the brain in neurodegenerative disorders, Int J Mol Sci, 16 (2015) 28194-28217.

[152] M.E. Rice, Ascorbate regulation and its neuroprotective role in the brain, Trends Neurosci, 23 (2000) 209-216.

[153] J.X. Wilson, C.E. Peters, S.M. Sitar, P. Daoust, A.W. Gelb, Glutamate stimulates ascorbate transport by astrocytes, Brain Res, 858 (2000) 61-66.

[154] U.V. Berger, M.A. Hediger, The vitamin C transporter SVCT2 is expressed by astrocytes in culture but not in situ, Neuroreport, 11 (2000) 1395-1399.

[155] J. Korcok, R. Yan, R. Siushansian, S.J. Dixon, J.X. Wilson, Sodium-ascorbate cotransport controls intracellular ascorbate concentration in primary astrocyte cultures expressing the SVCT2 transporter, Brain Res, 881 (2000) 144-151.

[156] L. Garcia Mde, K. Salazar, C. Millan, F. Rodriguez, H. Montecinos, T. Caprile, C. Silva, C. Cortes, K. Reinicke, J.C. Vera, L.G. Aguayo, J. Olate, B. Molina, F. Nualart, Sodium vitamin C cotransporter SVCT2 is expressed in hypothalamic glial cells, Glia, 50 (2005) 32-47.

[157] U.V. Berger, X.C. Lu, W. Liu, Z. Tang, B.S. Slusher, M.A. Hediger, Effect of middle cerebral artery occlusion on mRNA expression for the sodium-coupled vitamin C transporter SVCT2 in rat brain, J Neurochem, 86 (2003) 896-906.

[158] N.J. Gerkau, R. Lerchundi, J.S.E. Nelson, M. Lantermann, J. Meyer, J. Hirrlinger, C.R. Rose, Relation between activity-induced intracellular sodium transients and ATP dynamics in mouse hippocampal neurons, J Physiol, (2019). [159] C.R. Rose, C. Karus, Two sides of the same coin: sodium homeostasis and signaling in astrocytes under physiological and pathophysiological conditions, Glia, 61 (2013) 1191-1205.

[160] C.R. Rose, J.Y. Chatton, Astrocyte sodium signaling and neuro-metabolic coupling in the brain, Neuroscience, 323 (2016) 121-134.

[161] C.R. Rose, B.R. Ransom, Intracellular sodium homeostasis in rat hippocampal astrocytes, J Physiol, 491 ( Pt 2) (1996) 291-305.

[162] C.R. Rose, B.R. Ransom, Mechanisms of $\mathrm{H}^{+}$and $\mathrm{Na}^{+}$changes induced by glutamate, kainate, and D-aspartate in rat hippocampal astrocytes, J Neurosci, 16 (1996) 5393-5404.

[163] C.R. Rose, B.R. Ransom, Regulation of intracellular sodium in cultured rat hippocampal neurones, J Physiol, 499 ( Pt 3) (1997) 573-587.

[164] N.M. Uwechue, M.C. Marx, Q. Chevy, B. Billups, Activation of glutamate transport evokes rapid glutamine release from perisynaptic astrocytes, J Physiol, 590 (2012) 2317-2331.

[165] C.R. Rose, D. Ziemens, V. Untiet, C. Fahlke, Molecular and cellular physiology of sodium-dependent glutamate transporters, Brain Res Bull, 136 (2018) 3-16. 
[166] J. Langer, J. Stephan, M. Theis, C.R. Rose, Gap junctions mediate intercellular spread of sodium between hippocampal astrocytes in situ, Glia, 60 (2012) 239-252. 
Figure legends

\section{Figure 1. Diversity of astrocytes}

Figure 2. Ionostatic astroglial transporters.

Abbreviations: NKA - $\mathrm{Na}^{+}-\mathrm{K}^{+}$ATPase; NBC - $\mathrm{Na}^{+} / \mathrm{HCO}_{3}{ }^{-}$(sodium-bicarbonate) cotransporter; NCX - $\mathrm{Na}^{+} / \mathrm{Ca}^{2+}$ exchanger; NCLX - mitochondrial $\mathrm{Na}^{+} / \mathrm{Ca}^{2+}$ exchanger; $\mathrm{NHE}-\mathrm{Na}^{+} / \mathrm{H}^{+}$exchanger; NKCC1 - $\mathrm{Na}^{+} / \mathrm{K}^{+} / \mathrm{Cl}^{-}$cotransporter,

Figure 3. Neurotransmitter astroglial transporters

Abbreviations: CNT2, concentrative nucleoside transporters; EAAT - excitatory amino acid transporters; GAT - GABA transporters; GlyT1-glycine transporter; NET - norepinephrine transporter; DAT - dopamine transporter; SERT - serotonin transporter; note that SERT stoichiometry is $1 \operatorname{serotonin}^{+}: 1 \mathrm{Na}^{+}: 1 \mathrm{Cl}^{-}$(in) $: 1 \mathrm{~K}^{+}$ (out)

Figure 4. Astroglial transporters for neurotransmitter precursors

Abbreviations: SNAT3/5 - sodium-coupled neutral amino acid transporters; ASCT2 neutral amino acid transporter

Figure 5. Metabolite astroglial transporters.

Abbreviations: NAAT - $\mathrm{Na}^{+}$-dependent ascorbic acid transporter; $\mathrm{MCT}$ monocarboxylase transporter; GLUT - glucose transporters.

Figure 6. $\mathrm{Na}^{+}$signalling and astroglial homeostatic function. 


\section{Astroglia}

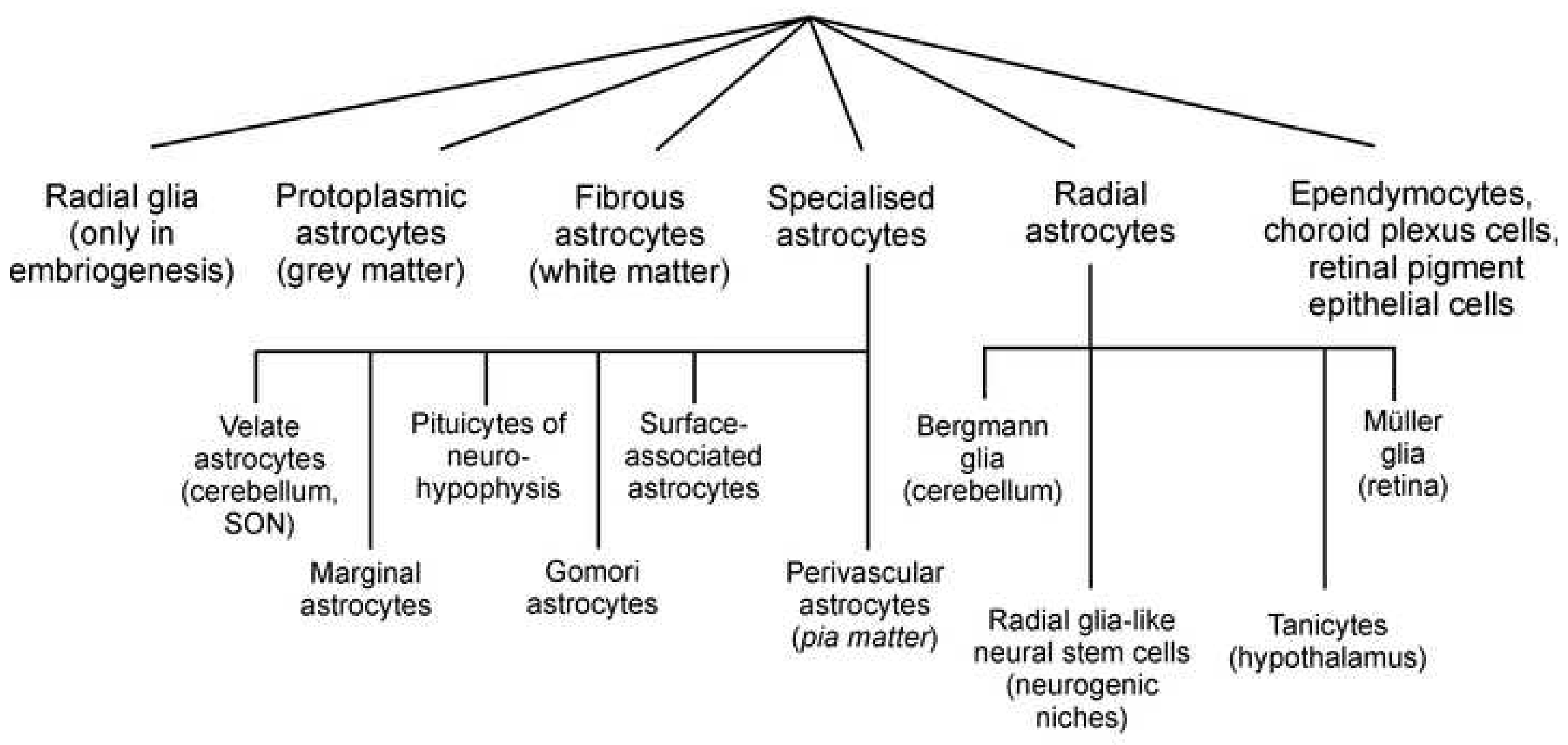

\begin{tabular}{|c|c|c|c|c|c|c|c|}
\hline $\begin{array}{l}\text { Radial glia } \\
\text { (only in } \\
\text { mbriogenesis) }\end{array}$ & \multicolumn{2}{|c|}{$\begin{array}{l}\text { Protoplasmic } \\
\text { astrocytes } \\
\text { (grey matter) }\end{array}$} & \multicolumn{2}{|c|}{$\begin{array}{c}\text { Fibrous } \\
\text { astrocytes } \\
\text { (white matter) }\end{array}$} & $\begin{array}{l}\text { Specialised } \\
\text { astrocytes }\end{array}$ & $\begin{array}{c}\text { Radial } \\
\text { astrocytes }\end{array}$ & $\begin{array}{l}\text { Ependymocytes, } \\
\text { choroid plexus cells, } \\
\text { retinal pigment } \\
\text { epithelial cells }\end{array}$ \\
\hline $\begin{array}{r}V_{\epsilon} \\
\text { astr } \\
\text { (cere } \\
\mathrm{S}\end{array}$ & $\begin{array}{l}\text { ate } \\
\text { ellum, } \\
\text { N) }\end{array}$ & $\begin{array}{r}\text { Pituic } \\
\text { ne } \\
\text { hypo }\end{array}$ & & $\begin{array}{l}\text { Surface- } \\
\text { associated } \\
\text { astrocytes }\end{array}$ & & $\begin{array}{l}\text { Jmann } \\
\text { lia } \\
\text { bellum) }\end{array}$ & $\begin{array}{l}\text { Müller } \\
\text { glia } \\
\text { (retina) }\end{array}$ \\
\hline & \multicolumn{2}{|c|}{$\begin{array}{l}\text { Marginal } \\
\text { astrocytes }\end{array}$} & \multicolumn{2}{|c|}{$\begin{array}{c}\text { Gomori } \\
\text { astrocytes }\end{array}$} & $\begin{array}{l}\text { Perivascular } \\
\text { astrocytes } \\
\text { (pia matter) }\end{array}$ & $\begin{array}{r}\text { Radial } \\
\text { neural s } \\
\text { (neur } \\
\text { nic }\end{array}$ & $\begin{array}{l}\text { tes } \\
\text { amus) }\end{array}$ \\
\hline
\end{tabular}

Fig. 1 


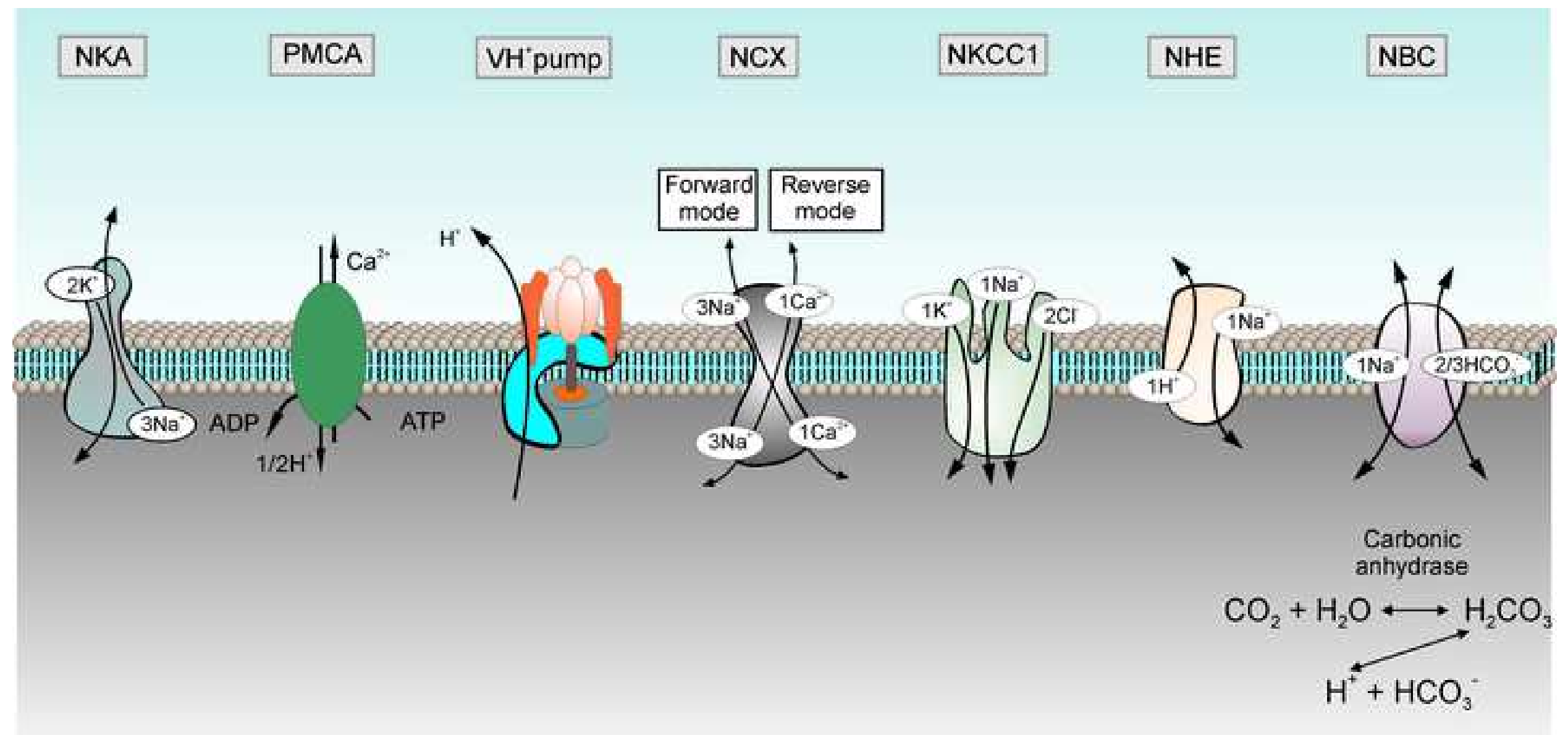

Fig. 2 


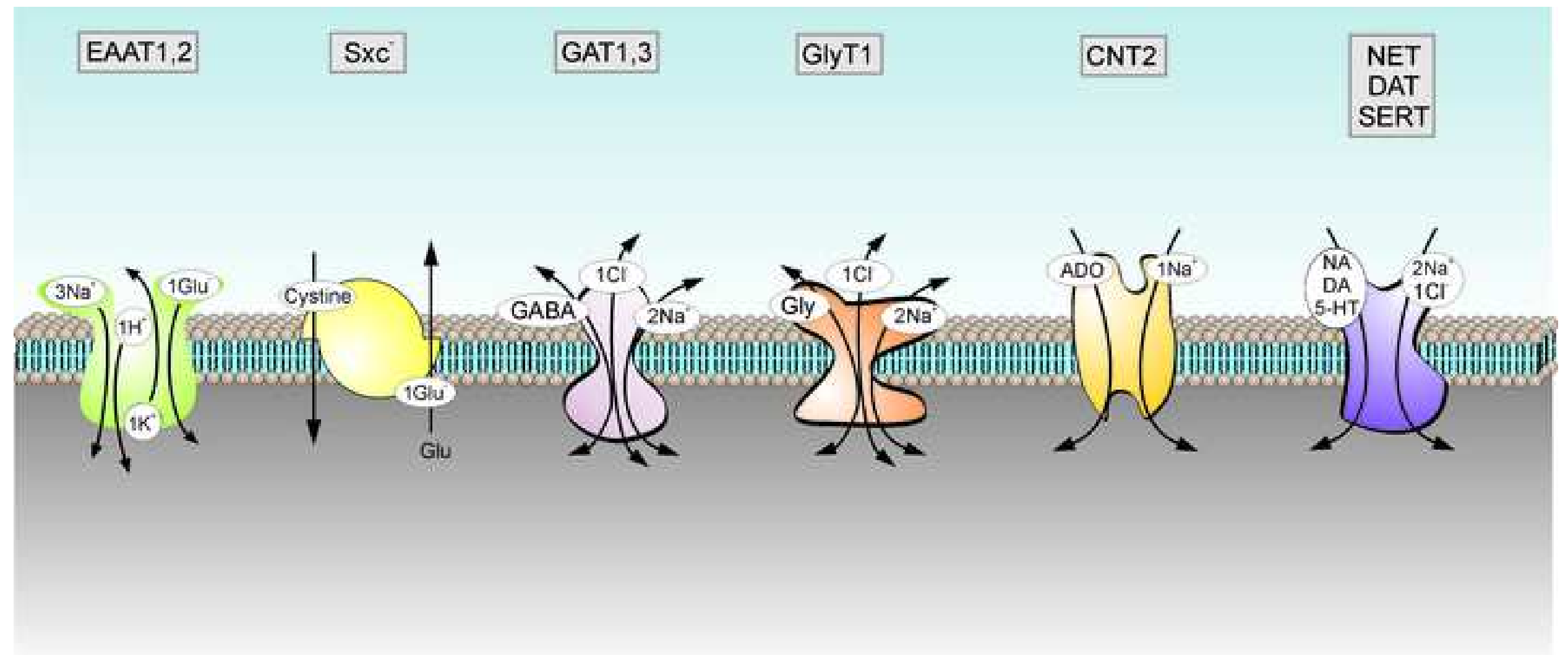

Fig. 3 


\section{SNAT3 SNAT5}

\section{ASCT2}

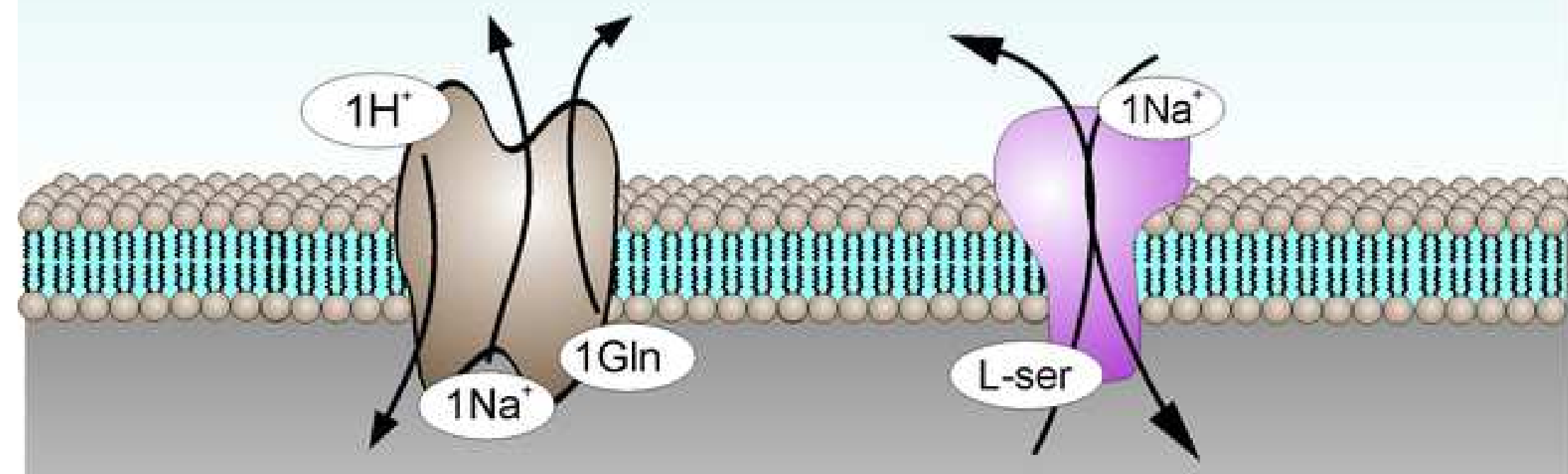

Fig. 4 


\section{MCT1}

\section{GLUT1}

NAAT

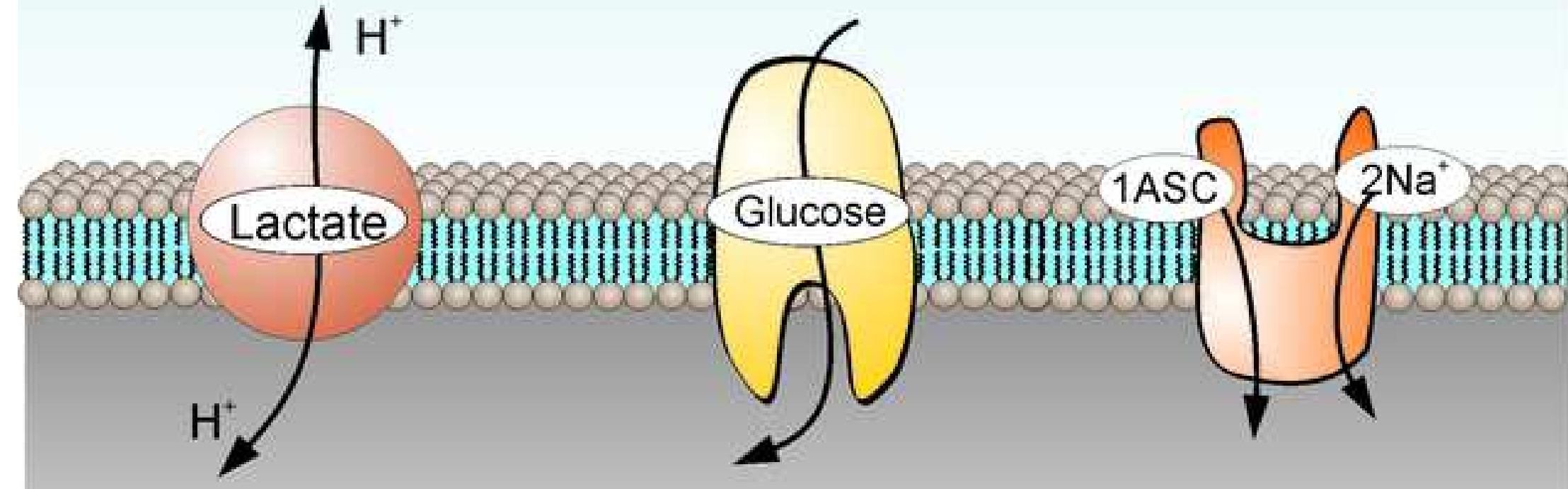

Fig. 5 


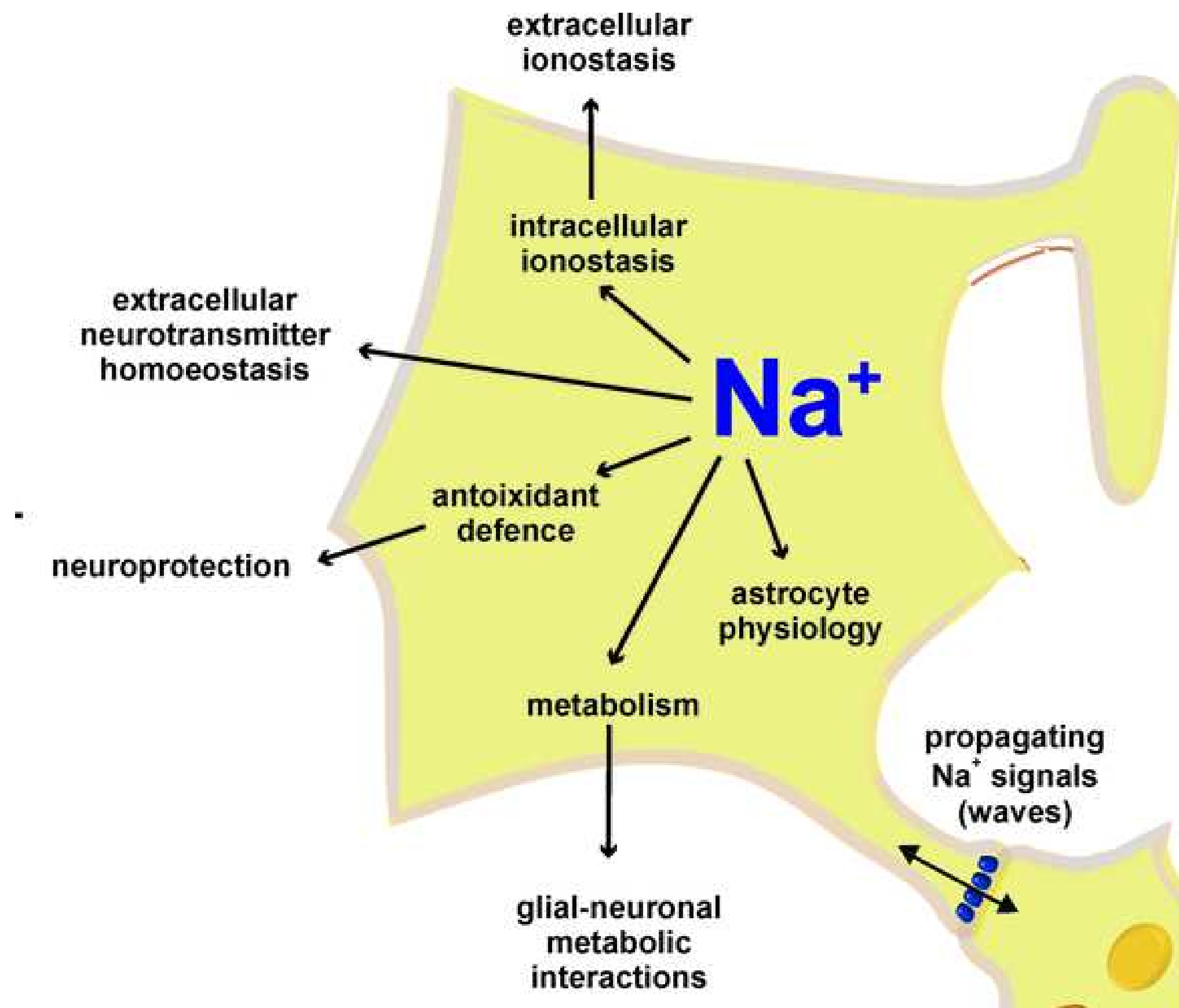

Fig. 6 


\section{Author Contribution Statement}

Authors contributed equally to the conceptualisation, writing and editing of this paper 